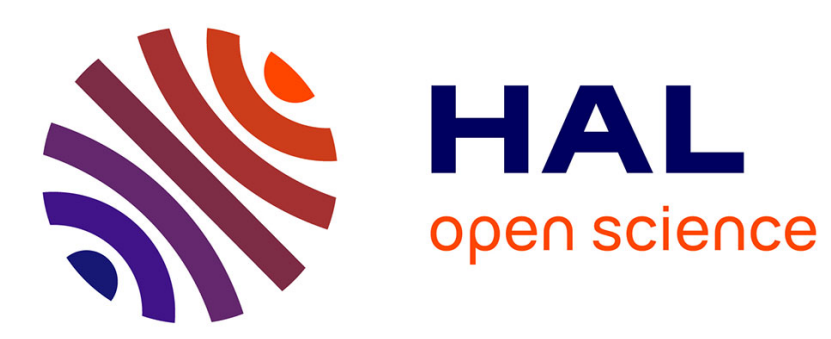

\title{
Diagnosis of trace metal contamination in sediments: the example of Ensenada and El Sauzal, two harbors in Baja California, Mexico
}

Miguel Angel Huerta-Diaz, Francisco Delgadillo-Hinojosa, Martín Hernández-Ayón, José Antonio Segovia-Zavala, Zaúl García-Esquivel, Héctor López-Zárate, Arturo Siqueiros-Valencia, Salvador Galindo-Bect

\section{To cite this version:}

Miguel Angel Huerta-Diaz, Francisco Delgadillo-Hinojosa, Martín Hernández-Ayón, José Antonio Segovia-Zavala, Zaúl García-Esquivel, et al.. Diagnosis of trace metal contamination in sediments: the example of Ensenada and El Sauzal, two harbors in Baja California, Mexico. Marine Environmental Research, 2008, 66 (3), pp.345. 10.1016/j.marenvres.2008.05.008 . hal-00563036

\section{HAL Id: hal-00563036 https://hal.science/hal-00563036}

Submitted on 4 Feb 2011

HAL is a multi-disciplinary open access archive for the deposit and dissemination of scientific research documents, whether they are published or not. The documents may come from teaching and research institutions in France or abroad, or from public or private research centers.
L'archive ouverte pluridisciplinaire HAL, est destinée au dépôt et à la diffusion de documents scientifiques de niveau recherche, publiés ou non, émanant des établissements d'enseignement et de recherche français ou étrangers, des laboratoires publics ou privés. 


\section{Accepted Manuscript}

Diagnosis of trace metal contamination in sediments: the example of Ensenada and El Sauzal, two harbors in Baja California, Mexico

Miguel Angel Huerta-Diaz, Francisco Delgadillo-Hinojosa, Martín HernándezAyón, José Antonio Segovia-Zavala, Zaúl García-Esquivel, Héctor López-

Zárate, Arturo Siqueiros-Valencia, Salvador Galindo-Bect

PII:

S0141-1136(08)00162-1

DOI: 10.1016/j.marenvres.2008.05.008

Reference: MERE 3260

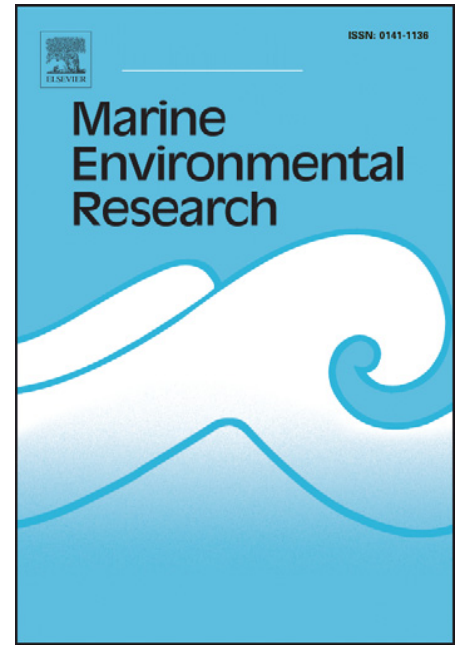

To appear in:

\section{Marine Environmental Research}

Received Date: $\quad 8$ May 2007

Revised Date: $\quad 1$ May 2008

Accepted Date: $\quad 15$ May 2008

Please cite this article as: Huerta-Diaz, M.A., Delgadillo-Hinojosa, F., Hernández-Ayón, M., Segovia-Zavala, J.A., García-Esquivel, Z., López-Zárate, H., Siqueiros-Valencia, A., Galindo-Bect, S., Diagnosis of trace metal contamination in sediments: the example of Ensenada and El Sauzal, two harbors in Baja California, Mexico, Marine Environmental Research (2008), doi: 10.1016/j.marenvres.2008.05.008

This is a PDF file of an unedited manuscript that has been accepted for publication. As a service to our customers we are providing this early version of the manuscript. The manuscript will undergo copyediting, typesetting, and review of the resulting proof before it is published in its final form. Please note that during the production process errors may be discovered which could affect the content, and all legal disclaimers that apply to the journal pertain. 


\section{Diagnosis of trace metal contamination in sediments: the example of Ensenada and El Sauzal, two harbors in Baja California, Mexico}

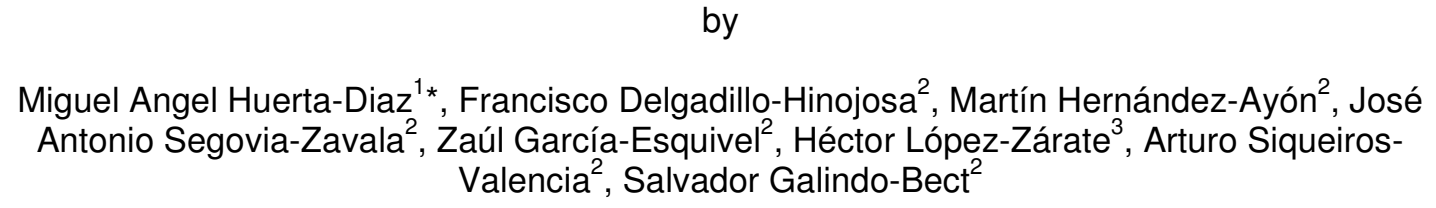

1 Instituto de Investigaciones Oceanológicas, Universidad Autónoma de Baja California, PMB133, P.O. Box 189003, Coronado, CA 92178-9003, USA.

2 Instituto de Investigaciones Oceanológicas, Universidad Autónoma de Baja California, Campus Ensenada, km. 103 Carr. Tijuana-Ensenada, Ensenada, Baja California, México.

${ }^{3}$ Facultad de Ciencias Marinas, Posgrado en Oceanografía Costera, Universidad Autónoma de Baja California, Campus Ensenada, km. 103 Carr. Tijuana-Ensenada, Ensenada, Baja California, México.

* Corresponding author. Phone: +52-646-174-4601 x167; Fax: +52-646-174-5303; e-mail: mhuerta@uabc.mx, alternate e-mail: mhuertadiaz52@yahoo.com 


\section{Abstract}

26 Total metal concentrations in sediments from within Ensenada and El Sauzal harbors are

27 generally higher than at the mouths. Grain-size analyses suggested that this enrichment could

28 be due to the presence of fine-grained sediments in the inner part of the harbors rather than to

29 anthropogenic perturbations. The $(\mathrm{Me} / \mathrm{Al})_{\text {sample }}$ ratios for $\mathrm{Pb}, \mathrm{Co}, \mathrm{Ni}$ and Fe were significantly

30 higher for Ensenada Harbor relative to El Sauzal Harbor, whereas the ratios for Cd, Mn, Zn and

31 Cu were statistically equivalent for both harbors. Calculated enrichment factors $\left[E F_{M e}=\right.$

$32(\mathrm{Me} / \mathrm{Al})_{\text {sample }} /(\mathrm{Me} / \mathrm{Al})_{\text {shale }}$ indicated that the metals showing slight enrichment were those

33 associated with anthropogenic contamination $(\mathrm{Pb}, \mathrm{Zn})$, or probably related to primary productivity

34 in the water column (Cd, Co). The levels of most of the metals were not greatly enriched, a

35 consideration that is of the utmost importance when contamination issues are at stake.

37 Keywords: enrichment factor, geochemistry, grain size, metals, sediment pollution, trace

38 elements, Baja California. 


\section{Introduction}

40

Harbors are enclosed and low-energy water bodies where fine-grained sediment tends to accumulate. They are also prone to receive significant metal inputs from marinas, boat hull maintenance, wholesale fish markets, shipping activities, sacrificial anodes, and industrial, storm and urban discharges. Once in the water column, metals are quickly adsorbed onto particulates and eventually removed to bottom sediments (de Groot et al., 1982; Santschi et al., 1984; Blake et al., 2004), thus producing conspicuous trace metal enrichments. Moreover, trace metal enrichments in sediments produced by normal harbor activities can be further enhanced by the larger surface area of the finer sediments that are naturally deposited in these areas of minimum hydrodynamic energy. It is therefore important to measure the extent of metal enrichment in harbor sediments since they can act as point sources of contamination during dredging operations or any other activity by which contaminated sediments can be transported out of the harbors and into neighboring bays or open ocean areas.

Ensenada and El Sauzal harbors are the main harbors on the Pacific coast of northern Mexico. They are located in Todos Santos Bay (Figure 1) and plans are well underway to modernize both harbors by increasing their extension and container handling capacity, especially in the case of El Sauzal Harbor, whose area will be increased approximately ten times.

Additionally, Ensenada Harbor has a cruise terminal capable of handling at least two cruise ships simultaneously. All this expansion work and increase in shipping traffic are associated with dredging activities that may produce a net export of metals out of the harbors. Hence, understanding the relative contributions of the different trace metals is necessary in order to assess the impact of future developments in these harbors and their surrounding waters, and to develop effective strategies to protect them and other harbors elsewhere.

In this paper we will try to answer the following specific questions: Are sediments from Ensenada and El Sauzal harbors enriched in trace metals ( $\mathrm{Cd}, \mathrm{Co}, \mathrm{Cu}, \mathrm{Fe}, \mathrm{Mn}, \mathrm{Ni}, \mathrm{Pb}, \mathrm{Zn})$ ? If so, to what extent and with which metals? Which harbor presents the highest metal enrichments? If present, are these trace metal enrichments anthropogenically derived? To 
67 answer these questions, trace element levels (normalized with $\mathrm{Al}$ ) will be compared with those reported for other sediments from the Southern California Bight and with average shale values of sedimentary rocks to evaluate the extent of anthropogenic perturbations in the sediments of these two important Mexican harbors. Additionally, pollution load indexes (Tomlinson et al., 1980; Angulo, 1996) and geoaccumulation indexes (Müller, 1979) will be calculated for both harbors. Finally, total concentrations will be compared with the U.S. NOAA's sediment quality guidelines (as proposed by Long et al., 1995) to estimate the possible consequences of the metal levels analyzed in this study to the local biota. Because of the absence of similar studies in the region, this paper will also provide baseline data for future research on anthropogenic impacts in the 76 region.

\section{Materials and methods}

\subsection{Study area}

80

Ensenada and El Sauzal harbors are situated in Todos Santos Bay, which is located in

82 the northwestern part of the Baja California Peninsula, Mexico (Figure 1a), $100 \mathrm{~km}$ south of the 83 US-Mexico border ( $\left.31^{\circ} 40^{\prime}, 31^{\circ} 56^{\prime} \mathrm{N} ; 116^{\circ} 36^{\prime}, 116^{\circ} 50^{\prime} \mathrm{W}\right)$. This $240-\mathrm{km}^{2}$ bay is limited to the 84 south by Punta Banda, to the north by Punta San Miguel, to the southwest by two small islands 85 located near the mouth of the bay, and to the northeast by the city of Ensenada (around 400,000 86 inhabitants). According to Pavía (2004), the climate of the region is Mediterranean, with scarce 87 rainfall (annual average of $250 \mathrm{~mm}$ ) that occurs mainly during the winter (average of $200 \mathrm{~mm}$ ).

88 The regional surface circulation pattern is produced by a predominant northwest component of 89 the wind and surface currents have been reported to average $15 \mathrm{~cm} \mathrm{~s}^{-1}$ and $5 \mathrm{~cm} \mathrm{~s}^{-1}$ during 90 summer and winter, respectively (Alvarez-Sánchez et al., 1988). This wind-driven circulation 91 pattern promotes the transport of water from the adjacent Pacific Ocean towards the inner bay, 92 generating a cell circulation system (dotted arrows; Figure 1b). Part of this flow is directed toward 93 Ensenada harbor and the other part toward Punta Banda, in the southwestern part of the bay 
94 (Figure 1b). Upwelling is intense all year round, but especially in spring and summer (Gonzalez95 Morales and Gaxiola-Castro, 1991).

Ensenada Harbor, an international marine terminal, was built in 1956 and covers an area of $1.95 \mathrm{~km}^{2}$ (i.e., approximately 13 times bigger than El Sauzal Harbor). The mouth of the harbor is formed by a 1,640 -m-long rock breakwater that is connected to the coast and by a $855-\mathrm{m}$-long jetty (EI Gallo; Figure 1d). Water depths range from 1.5 to $11 \mathrm{~m}$, with the deepest parts located adjacent to the loading and terminal docks and the main navigation channel. In addition to the presence of fine-grained sediments (approximately $80 \%<62.5 \mu \mathrm{m}$ ), this harbor tends to accumulate metals due to inputs from (a) a wholesale fish market, (b) marine vessels normally docked in the port and marina areas, (c) urban runoff discharged through Arroyo Ensenada (Figure 1d) during the winter rains, and (d) vessel reparation and maintenance activities (liberation of antifouling paint, sand blasting operations) within the port zone. town of El Sauzal de Rodriguez (approximately 7,500 inhabitants), has an area of $0.15 \mathrm{~km}^{2}$ (Flores-Vidal et al., 2005) and a 100-m-wide mouth formed by two breakwaters that are $500 \mathrm{~m}$ and $250 \mathrm{~m}$ long (Figure 1c). Water depths range from 1 to $9 \mathrm{~m}$, with maximum depth occurring in the main navigation channel (Flores-Vidal et al., 2005). Inputs to this harbor are essentially from fishery companies dedicated to extraction, processing and production activities, as well as from

112 blood and organic wastes discharged by docked fishing boats, and from the powder generated 113 during the unloading of cement from large boats or vessels.

\subsection{Field and laboratory methods}

Sediment samples from Ensenada Harbor were obtained from one core (core 0E)

118 collected at approximately 6 m water depth on November 2, 1998 (Carreón-Martínez et al., 2001).

119 This core was collected within the dredged channel, close to Arroyo Ensenada and in front of the 120 cruise terminal, which was still not constructed at that time. Six more cores (cores $1 \mathrm{E}$ to $6 \mathrm{E})$ were 121 collected on January 8, 2002 at water depths of approximately $9 \mathrm{~m}$ (Figure 1d) and beneath the 
docks, considered the areas least affected by sediment resuspension and dredging. Sediments had a hydrogen sulfide smell, were black along the length of the cores and did not show any oxidized portion close to the sediment-water interface. Cores from El Sauzal Harbor were collected on September 29, 2004 (cores 1S to 4S) at water depths ranging from 6 to $9 \mathrm{~m}$ (Figure 1c). A polycarbonate plastic core liner $(7.2 \mathrm{~cm}$ internal diameter, $60 \mathrm{~cm}$ in length) was introduced into the sediment, retrieved and capped underwater by a diver who transferred it to a boat. Once on board, the core liner was capped with a plastic cap, sealed with electrical tape and transported to shore, where it was extruded and sliced every $1 \mathrm{~cm}$ with a plastic spatula. Each section was then transferred to a $50-\mathrm{mL}$ centrifuge polypropylene tube and stored at $-20^{\circ} \mathrm{C}$ for further laboratory analysis. Only core $0 \mathrm{E}$ was sliced in a glove bag under nitrogen atmosphere to avoid precipitation of the reduced $\mathrm{Fe}$ and $\mathrm{Mn}$ dissolved in the anoxic portion of the interstitial water. The $10-13 \mathrm{~cm}$ sediment depths of core $2 \mathrm{~S}$ consisted almost entirely of fish scales.

All laboratory materials were washed with phosphate-free soap, rinsed three times with distilled water and left for 24 hours in a $5 \% \mathrm{HCl}$ solution. The material was then rinsed three times with deionized water (Milli-Q grade) and left semi-closed to dry at room temperature. Total metal concentrations were obtained after complete digestion of $0.5 \mathrm{~g}$ of sediment in Teflon beakers with concentrated $\mathrm{HNO}_{3}, \mathrm{HClO}_{4}$ and $\mathrm{HF}$ (Carignan and Tessier, 1988). Trace metal concentrations were measured by atomic absorption spectrometry (Thermo Jarrel Ash model Smith Hieftje 12 or Varian model SpectrAA 220 Fast Sequential). Certified Reference Material (CRM) Beaufort Chemistry Standard Sediment (BCSS-1; National Research Council of Canada) was used to ascertain the accuracy and precision of the total extraction procedure. Recovery percentages of the BCSS-1 CRM ranged from $90 \%$ for $\mathrm{Cd}$ to $104 \%$ for $\mathrm{Cu}$ (Table 1). Blanks were routinely run and analyzed in the same manner as the samples. Limits of detection for the different trace metals, calculated as three times the standard deviation of the procedural blanks, were (in $\mu \mathrm{mol} \mathrm{g}{ }^{-1}$ ): 2.4 (Al), 0.0076 (Cd), 0.026 (Co), 0.024 (Cu), 0.014 (Fe), $0.0047(\mathrm{Mn}), 0.11$ (Ni), $0.035(\mathrm{~Pb}), 0.013(\mathrm{Zn})$. In this paper, and for practical purposes, all metals associated with sediments will be designated as trace metals, regardless of their concentration level. Percentage of sediment grain size $<62.5 \mu \mathrm{m}$ (\%GS) was measured using a Horiba laser scattering particle 
size distribution analyzer model LA-910, with size interval of $0.02-1000 \mu \mathrm{m}$. The analytical efficiency of the particle analyzer was determined with $0.9-\mu \mathrm{m}$ sieved polystyrene spheres (CRM NIST 8010D and NIST 1690). Organic carbon (org-C) concentrations in the sediments were estimated using the loss on ignition ( $\mathrm{LOI})$ method $\left(550^{\circ} \mathrm{C}\right.$ for $\left.5 \mathrm{~h}\right)$. These measurements were transformed to org- $C$ concentrations through a calibration curve (org- $\mathrm{C} \%=(0.206 \pm 0.010)^{*} \mathrm{LOI}$; $r^{2}=0.929, p<0.001, n=33$ ) using org- $C$ values from Todos Santos Bay sediments measured by a LECO model CHNS-932 elemental analyzer. Due to the lack of available samples, org-C and grain size were not measured in core $0 \mathrm{E}$.

To reduce the complexity within the similarity matrix, the dataset (including metal concentrations, org-C content and \%GS) was transformed into a simpler factor matrix by principal components analysis (PCA). For both Ensenada and El Sauzal harbors, the PCA was calculated based on the correlation matrix of the standardized data using the SYSTAT 8.0 statistical package. For this analysis, eigenvalues $>1$ were considered significant and, in addition, the

\section{Results and discussion}

\subsection{Trace metal distributions}

Trace metal profiles for both Ensenada and El Sauzal harbors showed no substantial changes in concentration with sediment depth (Figures 2 and 3), except for $\mathrm{Cu}$ and $\mathrm{Zn}$ in core 1E, in which peaks of maximum concentration $\left(229 \mu \mathrm{mol} \mathrm{g}^{-1}\right.$ and $30 \mu \mathrm{mol} \mathrm{g}^{-1}$, respectively; Figures 2c and 2i) were observed at a depth of $5.5 \mathrm{~cm}$ for both elements. The concentration of Cu was also

172 high in the first $6 \mathrm{~cm}$ of core 4E $\left(2.66 \pm 0.49 \mu \mathrm{mol} \mathrm{g}^{-1}\right)$, while $\mathrm{Cd}$ concentrations increased with 173 depth (maximum value $=0.018 \mu \mathrm{mol} \mathrm{g}^{-1}$ at $19.5 \mathrm{~cm}$ ) in the first $20 \mathrm{~cm}$ of core $0 \mathrm{E}$. Significant 174 trace metal enrichments close to the sediment-water interface are absent in both harbors, further 175 proof that the cores were anoxic up to the sediment-water interface. The lack of significant 176 features in all trace metal profiles is probably a consequence of the absence of the oxic layer 177 (and probably the anoxic non-sulfidic layer as well) and of the homogeneity of the \%GS (Figure 
178

179

2j). Bioturbation can be discarded as the cause since all the cores were anoxic-sulfidic up to the sediment-water interface.

Overall, trace metals in Ensenada Harbor showed a wide range of average concentrations (Table 2), the lowest corresponding to Cd (overall average $32 \pm 16 \mathrm{nmol} \mathrm{g}^{-1}$ ) and the highest to $\mathrm{Al}$ (overall average $3.81 \pm 0.75 \mathrm{mmol} \mathrm{g}^{-1}$ ). On average, core $1 \mathrm{E}$ showed the highest values for $\mathrm{Cu}\left(15 \pm 40 \mu \mathrm{mol} \mathrm{g}{ }^{-1}\right)$, Fe $\left(1.33 \pm 0.16 \mathrm{mmol} \mathrm{g}^{-1}\right), \mathrm{Mn}\left(12.7 \pm 2.5 \mu \mathrm{mol} \mathrm{g}^{-1}\right)$ and $\mathrm{Zn}\left(5.8 \pm 4.5 \mu \mathrm{mol} \mathrm{g}^{-1}\right)$; core $0 \mathrm{E}$ for Co $\left(1.79 \pm 0.45 \mu \mathrm{mol} \mathrm{g}^{-1}\right)$ and Ni $\left(2.136 \pm 0.046 \mu \mathrm{mol} \mathrm{g}^{-1}\right)$; core $2 \mathrm{E}$ for $\mathrm{Cd}\left(50.6 \pm 2.5 \mathrm{nmol} \mathrm{g}^{-1}\right)$ and $\mathrm{Al}\left(4.94 \pm 0.25 \mathrm{mmol} \mathrm{g}^{-1}\right)$; and core $6 \mathrm{E}$ for $\mathrm{Pb}(371 \pm 14)$ (Table 2). Metals ( $\mathrm{Co}, \mathrm{Cu}, \mathrm{Ni}, \mathrm{Zn}, \mathrm{Fe}$ and, to a certain extent, $\mathrm{Al}, \mathrm{Mn}$ and $\mathrm{Cd}$ ) and org-C generally decreased in concentration from the inner part of Ensenada Harbor to its mouth (Figure 4). This result is not unexpected since the inner portion of the harbor shows finer grain size (Figure 4), more shipping activity and less hydrodynamic energy than the outer parts. In this harbor, the deepest areas range from 8 to $12 \mathrm{~m}$ and the shallower parts from 2 to $6 \mathrm{~m}$. Cores $3 \mathrm{E}, 4 \mathrm{E}$ and $5 \mathrm{E}$ were taken just at the edge of the deep main channel and thus presented higher sand composition but also low metal concentrations (Figure 4). Sediments located at the mouth of the harbor presented low \%GS (reflecting a high level of hydrodynamic energy) and, consequently, high sand contents that diluted trace metal concentrations. Core $0 \mathrm{E}$, however, usually presented anomalous concentrations when compared with the other cores from Ensenada Harbor (Figure 4); for example, it had considerably higher median concentrations of $\mathrm{Co}, \mathrm{Fe}$ and $\mathrm{Ni}$, and lower median concentrations of $\mathrm{Cd}$ and $\mathrm{Pb}$ relative to the other cores. This anomalous behavior can be attributed to the location of the core, which was collected inside the dredged channel and close to the mouth of Arroyo Ensenada. Sediment resuspension produced by continuous shipping traffic, repeated dredgings (which can alter the distribution of some key components of sediments, like nutrients and carbon; Nayar et al., 2007) and occasional particulate and dissolved contributions from the seasonal stream have evidently altered the distribution and levels of trace metals in core $\mathrm{OE}$. These alterations are more noticeable for $\mathrm{Cd}, \mathrm{Co}, \mathrm{Fe}, \mathrm{Mn}, \mathrm{Pb}$ and $\mathrm{Zn}$, as reflected in the variability (spread) of their concentrations (Figures 2a,b,d,f,h and i, respectively) and by the increase in length of the box plots shown in Figure 4.

page 7 (Huerta-Diaz et al.) 
Average metal concentrations in El Sauzal Harbor (Table 2) were consistently high in cores $2 \mathrm{~S}\left(\mathrm{Cd}=28.2 \pm 1.5 \mathrm{nmol} / \mathrm{g}, \mathrm{Cu}=1.24 \pm 0.13 \mu \mathrm{mol} \mathrm{g}^{-1}, \mathrm{Ni}=0.476 \pm 0.017 \mu \mathrm{mol} \mathrm{g}^{-1}, \mathrm{~Pb}=\right.$ $\left.183 \pm 18 \mathrm{nmol} \mathrm{g}^{-1}, \mathrm{Zn}=4.75 \pm 0.70 \mu \mathrm{mol} \mathrm{g}^{-1}\right)$ and $3 \mathrm{~S}\left(\mathrm{Al}=2.81 \pm 0.24 \mathrm{mmol} \mathrm{g}^{-1}, \mathrm{Co}=0.495 \pm\right.$ $0.037 \mu \mathrm{mol} \mathrm{g}^{-1}, \mathrm{Fe}=0.668 \pm 0.085 \mathrm{mmol} \mathrm{g}^{-1}, \mathrm{Mn}=7.6 \pm 1.1 \mu \mathrm{mol} \mathrm{g} \mathrm{g}^{-1}$ ). As in Ensenada Harbor, 210 trace metal enrichments close to the sediment-water interface are conspicuously absent for 211 practically all metals, suggesting that the cores were anoxic up to the sediment-water interface. Median concentration values were consistently high in cores 2S, 3S and 4S from the inner 213 stations and low in core $1 \mathrm{~S}$ from the harbor mouth, a reflection of the coarser grain size that 214 characterizes this last core (Figure 4). The bathymetry for this harbor (Flores-Vidal et al., 2005) 215 shows that cores $3 S$ and $4 S$ were located at approximately $9 \mathrm{~m}$ depth (i.e., the deepest inner 216 area), whereas cores $1 \mathrm{~S}$ and $2 \mathrm{~S}$ were collected at water depths of approximately $6 \mathrm{~m}$. Judging 217 from the grain size composition, station 1S was located where the hydrodymic energy was higher. Figure 4 shows that total concentrations of $\mathrm{Cd}, \mathrm{Co}, \mathrm{Fe}, \mathrm{Mn}, \mathrm{Ni}$ and $\mathrm{Pb}$ are generally lower 219 in El Sauzal Harbor than in Ensenada Harbor. These results probably cannot be ascribed to 220 differences in org- $C$ concentrations for Ensenada (1.50 $\left.\pm 0.38 \mathrm{mmol} \mathrm{g}^{-1} ; \mathrm{n}=139\right)$ and El Sauzal $221\left(1.78 \pm 0.97 \mathrm{mmol} \mathrm{g}^{-1} ; \mathrm{n}=74\right)$ harbors, since statistically both have similar average org-C levels $222(p=0.142$, Mann-Whitney rank sum test). The metal concentration results may suggest that Ensenada Harbor, which is approximately 30 years older than El Sauzal Harbor, tentatively has

224 had more time to accumulate trace metal contaminants in its sediments. Alternatively, the 225 sediments of both harbors may have, on average, different particulate sizes. A Mann-Whitney 226 rank sum test of the \%GS indicated that the average fraction $<62.5 \mu \mathrm{m}$ from Ensenada Harbor $227(80 \pm 18 \%, \mathrm{n}=182)$ was significantly higher $(p \leq 0.001)$ than the one measured for El Sauzal (73 $228 \pm 14 \%, n=74)$. The differences in \%GS distribution between the two harbors are also noticeable 229 in Figure 5, in which plots of metal concentrations versus \%GS are displayed. This figure shows 230 that the sediments from El Sauzal (closed symbols) form distinctly different groups for Co, $\mathrm{Fe}, \mathrm{Ni}$, $231 \mathrm{Mn}, \mathrm{Pb}$ and $\mathrm{Cd}$, which tend to cluster in the lower portion of the concentration range and 232 generally below the concentrations measured in Ensenada Harbor (open symbols). One of the 233 most important factors controlling the natural distribution of trace metals in sediments is the 
variation in grain size (Cauwet, 1987; Grant, 1990; Ergin, 1995; Lin et al., 2002). It is widely

235 accepted that metals are enriched in the fine $(<62.5 \mu \mathrm{m})$ fraction of sediments (Gibbs, 1977;

236 Helmke et al., 1977; de Groot et al., 1982; Förstner, 1982; Cauwet, 1987; Horowitz et al., 1989;

237 Zhang et al., 2002) and that metals exhibit positive linear correlations with the fine-grained sizes

238 (de Groot et al., 1982; Ackermann et al., 1983; Ergin, 1995; Meador et al., 1998; Charlesworth

239 and Service, 2000; Zhang et al., 2002). Although grain size analysis is not suitable for

240 differentiating natural baseline versus anthropogenic enrichments of trace elements, such an

241 analysis may help to account for the natural diluting effect of sand.

\subsection{Trace metals and grain size}

244

The size-class distribution in sediments is intimately related to the hydrodynamics of the systems. Hence, comprehension of this process in combination with coastal topography can help to understand the behavior of sediments in terms of flocculation, adsorption or precipitation. Based on textural parameters, Pérez-Higuera and Chee-Barragán (1984) inferred the existence of a southward dominant transport in the littoral zone of Todos Santos Bay. In the case of Ensenada Harbor, the water flow across the mouth produced by the tide effect is considered to be the main hydrodynamic forcing in the movement of particulate material, sediments and pollutants (Coronado-Méndez et al., 2003). The high sand contents (and low metal 254 mouths. measured in Ensenada and El Sauzal harbors were higher than those measured at the Point Loma Ocean Outfall (PLOO) discharge point and its surroundings, off San Diego Bay (City of San

258 Diego, 2005). This is surprising, considering that sediments from the PLOO area have been 259 found to be contaminated with a number of trace metals ( $\mathrm{Sb}, \mathrm{As}, \mathrm{Ba}, \mathrm{Be}, \mathrm{Cd}, \mathrm{Cr}, \mathrm{Cu}, \mathrm{Fe}, \mathrm{Pb}, \mathrm{Mn}$, $260 \mathrm{Hg}, \mathrm{Ni}$; City of San Diego, 2005). Furthermore, data reported for the Southern California Bight 261 (SCB; Schiff, 2000) show that average $\mathrm{Cu}$, Ni and $\mathrm{Zn}$ values for the whole SCB $\left(3,420.3 \mathrm{~km}^{2}\right)$ 
follow the same trends as the ones observed for Ensenada and El Sauzal harbors (Figures

$2635 \mathrm{c}, \mathrm{f}, \mathrm{h}$ ). Only $\mathrm{Cd}$ and $\mathrm{Pb}$ (Figures 5a, g) exhibited a differential behavior, with average SCB

264 concentrations well below the ones observed for Ensenada and El Sauzal sediments (Co, Fe and

265 Mn were not measured by Schiff, 2000). Similar results (Figure 5) were obtained for the average

266 values of Santa Monica Bay (SMB, $\left.457.4 \mathrm{~km}^{2}\right)$, outfalls of publicly owned treatment works

267 (POTWs, $292.8 \mathrm{~km}^{2}$ ) and stormwater areas (STW, $81.1 \mathrm{~km}^{2}$ ), the latter located within $3 \mathrm{~km}$ of the

26811 largest river and creek mouths draining directly into the SCB (Schiff, 2000). Pristine

269 sediments from Strangford and Carlingford loughs (Charlesworth and Service, 2000), as well as

270 from anthropogenically impacted regions of Mexico (Mazatlan Harbor: contaminated with oil,

271 sewage and industrial discharges; Osuna-López et al., 1986) and Europe (Belfast Lough:

272 domestic and industrial inputs from the city of Belfast; Charlesworth and Service, 2000) follow

273 trends similar to the ones observed for Ensenada and El Sauzal sediments (Figure 5). Only Ni

274 and, to a certain extent, $\mathrm{Zn}$ in the Belfast samples show higher concentrations than those

275 measured for sediments with similar \%GS. Hence, apparently the grain size:metal relationship is

276 not a useful indicator of trace metal enrichment: sediments with similar \%GS, but far more

277 contaminated by sewage effluents and industrial inputs (e.g., San Diego-PLOO, Los Angeles-

278 SMB, Belfast) than our study area have metal concentrations that are generally below or at the

279 same level as the ones measured in Ensenada and El Sauzal harbors (Figure 5).

3.3. Organic carbon

depth (except core 2E, Figure 2k), but without any noticeable trend. In contrast, El Sauzal Harbor showed no substantial changes with depth, except core 2S. This core had the highest concentrations of the four cores, probably because it was collected where docked fishing boats wash their decks, discharging in the process blood and organic wastes into the water and underlying sediment. The concentrations of org-C in core 2S were especially high between 8 and

$28913 \mathrm{~cm}$ (Figure 3k), probably reflecting past high inputs of organic wastes, whose degraded 
remains are represented by the $10-13 \mathrm{~cm}$ sediment depth, consisting almost entirely of fish scales. Additionally, this core showed anomalously high org- $\mathrm{C}$ concentrations with respect to the \%GS $\mu \mathrm{m}$ (Figure 5i), suggesting that anthropogenic contributions are considerable in the west corner of the harbor (core 2S, Figure 1). There was a significant correlation between \%GS and org- $C$ for both El Sauzal $(r=0.54, p \leq 0.001, n=74)$ and Ensenada $(r=0.71, p \leq 0.001, n=139)$ harbors (Table 3); however, the correlation for El Sauzal increased substantially when core 2S was eliminated ( $r=0.84, p \leq 0.001, n=61$; data not shown), further supporting the contention of the anthropogenic origin of the sedimentary org-C.

\subsection{Correlations between the different sediment components}

Results of the PCA analysis (Table 4) show that two components explained $79.9 \%$ and

$81.4 \%$ of the total variance for Ensenada and El Sauzal, respectively. In the case of Ensenada, a firmly related group (PC1) was formed by $\mathrm{Al}, \mathrm{Cd}, \mathrm{Co}, \mathrm{Fe}, \mathrm{Mn}, \mathrm{Ni}, \mathrm{Pb}$ and \%GS (loadings $>0.63$ ), while the second group (PC2) was formed by $\mathrm{Cu}, \mathrm{Zn}$ and org-C (loadings $>0.75$ ). For El Sauzal Harbor, $\mathrm{Cd}, \mathrm{Cu}, \mathrm{Zn}$ and org-C (loadings $>0.89$ ) constituted the first group (PC1), and Al, Co, Fe, $\mathrm{Mn}$ and \%GS the second (PC2; loadings >0.76). The strong correlation among $\mathrm{Cu}, \mathrm{Zn}, \mathrm{Cd}$ and org- $\mathrm{C}$ found for both harbors reflects the complex nature of organic matter as well as the importance of the role played by the diagenetic reactions driven by its degradation, which, in turn, regulates the behavior of these reactive metals. The strong association among $\mathrm{Al}, \mathrm{Fe}, \mathrm{Mn}, \mathrm{Co}$ and \%GS suggests that the concentrations of these metals are strongly controlled by the sediment grain size of these two Mexican harbors. The PCA results are essentially in agreement

313 of $\mathrm{Cd}, \mathrm{Cu}$ and $\mathrm{Zn}$ with organic matter and the existence of a strong lithogenous component (Al,

314 Fe and \%GS) controlling the distribution of trace metals in sediments. 
Another approach by which trace element enrichments can be evaluated consists of the geochemical normalization of metal concentrations with a conservative element. This approach is based on the assumption that there are certain elements that represent proxies for the clay mineral concentration (Kersten and Smedes, 2002). Geochemical normalization has several advantages. For example, it compensates for the mineralogical as well as the natural grain size variability of trace element concentrations in sediment (Loring, 1991; Birch, 2003). Aluminum has been widely used as a normalizing agent for evaluating metal concentrations in estuarine and coastal sediments (e.g., Goldberg et al., 1979; Schropp et al., 1990; Summers et al., 1996; Weisberg et al., 2004). Some of the main advantages of using Al as a geochemical normalizer are its high natural concentration (second most abundant metal in the Earth's crust), minimal anthropogenic contamination, it is a structural element of clays, and the metal to Al proportions in the crust are relatively constant (Schropp et al., 1990; Summers et al., 1996). Although Fe has also been used to normalize metal concentrations (e.g., Schiff and Weisberg, 1999), Al is a better agent because it is more strongly associated with the aluminosilicate matrix (one of the most important metal-bearing phases of sediments). In contrast, Fe can be significantly affected by 333 diagenetic processes (redistribution, anthropogenically induced formation of Fe sulfides and Fe oxides; Summers et al., 1996), which can distort total Fe concentrations (Loring, 1991). Metal/aluminum (Me/Al) ratios for both Ensenada and El Sauzal harbors increase in the 336 following order: $\mathrm{Cd} / \mathrm{Al}<\mathrm{Pb} / \mathrm{Al}<\mathrm{Ni} / \mathrm{Al} \approx \mathrm{Co} / \mathrm{Al} \approx \mathrm{Cu} / \mathrm{Al}<\mathrm{Zn} / \mathrm{Al}<\mathrm{Mn} / \mathrm{Al}<<\mathrm{Fe} / \mathrm{Al}$ (Figure 6). The $337 \mathrm{Me} / \mathrm{Al}$ ratios of $\mathrm{Pb}, \mathrm{Co}, \mathrm{Ni}$ and Fe were significantly higher for Ensenada Harbor relative to $\mathrm{El}$ 338 Sauzal Harbor, whereas the ratios for $\mathrm{Cd}, \mathrm{Mn}, \mathrm{Zn}$ and $\mathrm{Cu}$ were statistically equivalent for both 339 harbors. Hence, geochemical normalization suggests that metal concentrations in sediments 340 from El Sauzal show some similarities with those from Ensenada Harbor, but that the latter 341 sediments are more enriched in some elements. Proximity to a larger urban settlement (City of 342 Ensenada) may explain the higher $\mathrm{Pb} / \mathrm{Al}$ ratio for Ensenada; however, explaining the higher 343 values for the other three metal ratios is more difficult. It can be hypothesized that the presence 344 of more intense reducing conditions and greater flushing times (due to its smaller size) in El 345 Sauzal Harbor may explain the deficiency in $\mathrm{Fe}, \mathrm{Pb}, \mathrm{Co}, \mathrm{Ni}$ and, to a certain extent, Mn. Fishing 
boats are routinely cleaned inside this harbor and blood and organic waste end up accumulating

347 in the sediments. For example, the last $6 \mathrm{~cm}(7-13 \mathrm{~cm}$ interval) of core $2 \mathrm{~S}$ were almost entirely

348 made up of fish scales, an indirect indication of the magnitude of organic matter contribution to

349 the sediments. All this waste could conceivably drive the sediment redox conditions toward a

350 reducing condition, which is probably not so intense in Ensenada Harbor due to the absence of

351 this type of wastes. Fe and Mn are dynamic participants in the redox cycle and their more active

352 reductive dissolution in the El Sauzal sediments with subsequent diffusion to the water column,

353 coupled with a rapid flushing out of this harbor may explain the differences between $\mathrm{Fe} / \mathrm{Al}$ and

$354 \mathrm{Mn} / \mathrm{Al}$ in El Sauzal and Ensenada sediments. However, since the reaction of $\mathrm{Mn}$ with oxygen is

355 several orders of magnitude slower than that for reduced Fe (Jørgensen and Boudreau, 2001),

356 Mn will be preferentially lost to the water column due to its slower oxidation kinetics of

357 precipitation. Cobalt enrichment could be associated with primary productivity since this element

358 is associated with vitamin B12 (cobalamin), an essential component for the growth of many

359 phytoplankton species (Okbamichael and Sañudo-Wilhelmy, 2004). Furthermore, high

360 concentrations of dissolved B12 are generally found in shallow harbors and bays with limited

361 flushing (Okbamichael and Sañudo-Wilhelmy, 2004), characteristics that should favor the

362 accumulation of $\mathrm{Co}$ in Ensenada Harbor.

It is generally accepted that for the calculation of metal enrichments it is preferable to use

364 regional pre-industrial background concentrations. However, since no such information was

365 available for the study area, the values of Turekian and Wedepohl (1961) and Li and

366 Schoonmaker (2005) for the average composition of shale were used instead. The enrichment

367 factor $\left(\mathrm{EF}_{\mathrm{Me}}\right)$ was simply calculated as:

$$
\mathrm{EF}_{\mathrm{Me}}=\left(\frac{(\mathrm{Me} / \mathrm{Al})_{\text {sample }}}{(\mathrm{Me} / \mathrm{Al})_{\text {shale }}}\right)
$$

371 If $\mathrm{EF}_{\mathrm{Me}}>1$, the metal concentration in the sample is enriched relative to the average shale values 372 and, maybe, anthropogenically impacted. If $\mathrm{EF}_{\mathrm{Me}}<1$, then the metal is impoverished relative to 
373 the average shale values and, probably, subjected to a diagenetic process that reduces its 374 concentration in the sample. Finally, if $\mathrm{EF}_{\mathrm{Me}}=1$, then the metal concentration has the same 375 value as the reference value (normalized with $\mathrm{Al}$ ). The results of this exercise are shown in 376 Figure 7, where each core from Ensenada and El Sauzal harbors was plotted against the corresponding $\mathrm{EF}_{\mathrm{Me}}$ value. Values ranged from $0.41\left(\mathrm{EF}_{\mathrm{Cu}}\right.$, core $\left.5 \mathrm{E}\right)$ to $13\left(\mathrm{EF}_{\mathrm{Cu}}\right.$, core $\left.1 \mathrm{E}\right)$, and

378 from $0.36\left(\mathrm{EF}_{\mathrm{Ni}}\right.$, core $\left.4 \mathrm{~S}\right)$ to $12\left(\mathrm{EF}_{\mathrm{Cd}}\right.$, core $\left.2 \mathrm{~S}\right)$. Based on the $\mathrm{EF}_{\mathrm{Me}}$ values, the elements were 379 arbitrarily divided into four groups: (1) those highly enriched $\left(E F_{M e}>2.5\right)$ in the harbor sediments, represented solely by $\mathrm{Cd}$ (average $\mathrm{EF}_{\mathrm{Me}}$ value of $10 \pm 3$ ); (2) those slightly enriched $\left(1.5>\mathrm{EF}_{\mathrm{Me}}>\right.$ 2.5), represented by $\mathrm{Zn}$, Co and $\mathrm{Pb}$ (average $\mathrm{EF}_{\mathrm{Me}}$ values of $1.7 \pm 0.9,2.1 \pm 0.9$ and $2.3 \pm 0.5$, respectively); (3) those neither enriched nor impoverished $\left(0.6>E_{\mathrm{Me}}>1.5\right)$, represented (excluding core $1 \mathrm{E}$ ) by $\mathrm{Fe}$ and $\mathrm{Cu}$ (average $\mathrm{EF}_{\mathrm{Me}}$ values of $0.9 \pm 0.2$ and $1.2 \pm 0.6$, respectively); and (4) those slightly impoverished $\left(\mathrm{EF}_{\mathrm{Me}}<0.6\right)$, represented by $\mathrm{Mn}$ and $\mathrm{Ni}$ (average $\mathrm{EF}_{\mathrm{Me}}$ values of $0.50 \pm 0.06$ and $0.6 \pm 0.3$, respectively).

The high $\mathrm{EF}_{\mathrm{Me}}$ values of $\mathrm{Cd}$ may be a consequence of the Cd-enriched plankton (10 to 20 ppm; Martin and Broenkow, 1975) found in Baja California waters, which probably transfer this element to the sediments after their death and subsequent sedimentation. Additional $\mathrm{Cd}$ enrichment in the sediments can be produced by upwelling processes (Segovia-Zavala et al., 1998; Muñoz-Barbosa et al., 2004), which are common off the northwest coast of Baja California during spring and summer (Alvarez-Borrego and Alvarez-Borrego, 1982). The metals showing slight enrichment were those generally associated with anthropogenic contamination $(\mathrm{Pb}, \mathrm{Zn})$, or probably related to primary productivity and its relationship with vitamin $\mathrm{B} 12$, as was previously discussed for Co. However, it is surprising that Cu was among the metals neither enriched nor impoverished, since granular copper mine tailings were routinely employed to sandblast ships in a dry dock facility located adjacent to Ensenada Harbor. It is highly probable that the high enrichment value $\left(E F_{C u}=13\right)$ obtained for core $1 E$ (Figure 7) was due to the use of this sandblasting tailing. Impoverishment of $\mathrm{Mn}$ and $\mathrm{Ni}$ can be the result of the slow kinetics of precipitation of the former (Jørgensen and Boudreau, 2001), and the known association of the 400 latter with Mn oxides (Murray, 1975; Sclater et al., 1976; Balistrieri and Murray, 1986; Tessier et 
401

402

al., 1996; Kay et al., 2001; Trivedi and Axe, 2001), at least for the case of Ensenada Harbor, where a significant correlation was found between these two elements (Tables 3 and 4 ). Hence, $\mathrm{Ni}$ is probably released into the interstitial water upon reductive dissolution of the Mn oxides and, most likely, diffuses towards the sediment-water interface and is lost to the water column together with the dissolved Mn.

The average ratios of the Ensenada:El Sauzal enrichment factors (defined as $\left.\mathrm{EF}_{\mathrm{Me}(\text { Ensenada) }} / \mathrm{EF}_{\mathrm{Me}(\mathrm{El} \text { Sauzal) }}\right)$ ranged from $0.63 \pm 0.48$ for $\mathrm{Zn}$ to $2.9 \pm 12.4$ for $\mathrm{Cu}$ (Table 5). According to these results, only $\mathrm{Zn}$ and Cd concentrations were higher in El Sauzal Harbor, whereas the rest of the metals were more concentrated in Ensenada Harbor, especially Cu with a ratio of $2.9 \pm 12.4$. However, if the anomalously high $\mathrm{EF}_{\mathrm{Me}}$ results for some of the cores are removed from the calculation of the average ratio (e.g., $\mathrm{Cd}$ and Ni without core $0 \mathrm{E}$ and $\mathrm{Cu}$ without core $1 \mathrm{E}$ ), then the values are very close to unity for most of the metals (Table 5). Since a value of 1.0 would indicate that total metal concentrations in the sediments of both harbors are equal, these results suggest that $\mathrm{Zn}$ is the only metal whose concentrations are generally higher in $\mathrm{El}$ Sauzal, while Co is higher in Ensenada ( $0.63 \pm 0.48$ and $1.7 \pm 0.8$, respectively; Table 5). Furthermore, the $\mathrm{EF}_{\mathrm{Me}}$ values calculated from reported concentrations of pristine (Strangford and Carlingford loughs; Charlesworth and Service, 2000) and anthropogenically impacted areas (Belfast Lough and PLOO; Charlesworth and Service, 2000; City of San Diego, 2005) were approximately equal or generally higher for $\mathrm{Cu}, \mathrm{Fe}, \mathrm{Mn}, \mathrm{Ni}, \mathrm{Pb}$ and $\mathrm{Zn}$ than the values measured for Ensenada and El Sauzal harbors (Figure 7).

\subsection{Pollution Load Index}

The pollution load index (PLI) for a given core or zone is calculated from the contamination factors $\left(\mathrm{CF}_{\mathrm{Me}}=\right.$ concentration in sediment/base value for that metal) of each of its constituent samples, according to the following equation (Tomlinson et al., 1980):

$$
\mathrm{PLI}=\left(\mathrm{CF}_{\mathrm{Cd}} \times \mathrm{CF}_{\mathrm{Co}} \times \mathrm{CF}_{\mathrm{Cu}} \times \mathrm{CF}_{\mathrm{Ni}} \times \mathrm{CF}_{\mathrm{Pb}} \times \mathrm{CF}_{\mathrm{Zn}}\right)^{1 / 6}
$$


430 where the metal base value represents its average concentration in shale (Turekian and

431 Wedepohl, 1961; Li and Schoonmaker, 2005). According to Tomlinson et al. (1980), PLI values

432 of zero, one, or larger than one suggest absence of baseline pollutants, presence of them, or 433 progressive deterioration of sediment quality, respectively. Figure 8 shows that for Ensenada

434 Harbor, the core closer to the value of baseline pollutants (1.24) was 5E (at the harbor mouth), 435 whereas the innermost core 1E had the highest PLI value (4.29). The other cores showed values 436 between 1.97 and 2.89, with an overall value for the zone of 2.47 (“Ens" black bar in Figure 8).

437 The PLI values calculated for El Sauzal Harbor suggest that this zone is appreciably less 438 impacted by metal pollutants than Ensenada, ranging from 1.01 (core $1 \mathrm{~S}$ at the harbor mouth) to 4391.99 (core 2S), with a zonal value of 1.51 ("Sauz" black bar in Figure 8), equivalent to $61 \%$ of the 440 overall value for Ensenada Harbor. Hence, as a rule, the cores collected at both harbor mouths 441 had the lowest PLI values, whereas the inner cores had the highest values.

\subsection{Geoaccumulation index}

The geoaccumulation index $\left(I_{\text {geo }}\right)$, introduced by Müller (1981), has been used to quantitatively measure metal pollution in aquatic sediments (e.g., Santos Bermejo et al., 2003),

447 based on a pollution intensity classification ( $I_{\text {geo }}$ class) that consists of 7 grades or classes ( 0 to 6 ,

448 Table 6), the highest grade reflecting a 100-fold enrichment above baseline values. The $I_{\text {geo }}$ can 449 be calculated using the equation (Müller, 1979):

$$
\mathrm{I}_{\text {geo }}=\log _{2} \frac{[\mathrm{Me}]_{\text {studied area }}}{1.5[\mathrm{Me}]_{\text {baseline }}}
$$

453 where $[\mathrm{Me}]_{\text {baseline }}$ represents the metal concentration in average shales taken from Turekian and

454 Wedepohl (1961) and Li and Schoonmaker (2005), with a "1.5" factor included because of 455 possible variations in the background data due to lithogenic effects (Salomons and Förstner, 
1984). Results from this exercise indicated that $79.3 \%$ (Ensenada Harbor) and $86.1 \%$ (El Sauzal

Harbor) of the elements belonged to $I_{\text {geo }}$ classes 0 and 1 (unpolluted to moderately polluted), with only $6.3 \%$ (Ensenada Harbor only) positioned in $I_{\text {geo }}$ class 4 (0\% for El Sauzal Harbor; Table 6).

The only element that consistently ranked high in the $I_{\text {geo }}$ classes (3 or 4), for both harbors and all cores (except $0 \mathrm{E})$, was $\mathrm{Cd}$ (Table 6). It is clear that Ensenada has more metals in the "polluted" $I_{\text {geo }}$ classes (2 to 6; Table 6) than El Sauzal (20.6\% vs. $13.9 \%$, respectively). None of the analyzed elements were positioned in the last two, more polluted classes (5 and 6).

\subsection{Sediment quality guidelines}

Comparison of our total concentrations with the NOAA's sediment quality guidelines

467 (Long et al., 1995) can be used to evaluate the possible biological consequences of the levels of 468 metals in Ensenada and El Sauzal harbors. Long et al. (1995) matched biological and chemical data compiled from numerous modeling, laboratory, and field studies performed in marine and

470 estuarine sediments. Using these data, effects range-low (ERL: lower 10th percentile of the 471 effects data) and range-median (ERM: the median, or 50th percentile, of the effects data)

472 guideline values were determined for a number of metals (Table 7: guideline values available only 473 for $\mathrm{Cd}, \mathrm{Cu}, \mathrm{Ni}, \mathrm{Pb}$ and $\mathrm{Zn})$. These two guideline values (ERL and $\mathrm{ERM}$ ) delineate three 474 concentration ranges ( $<E R L, E R L-E R M,>E R M)$ for a particular metal. Hence, concentrations 475 below the ERL value will represent a minimal-effects range, a range intended to estimate 476 conditions in which biological effects would be rarely observed. Concentrations equal to and 477 above the ERL, but below the ERM, will represent a possible-effects range within which effects 478 would occasionally occur. Finally, concentrations equivalent to and above the ERM value will 479 represent a probable-effects range within which effects would frequently occur (Long et al., 1995). 480 Table 7 shows that there is a considerable difference between the two harbors in the allocation of $481 \mathrm{Cu}, \mathrm{Ni}$ and $\mathrm{Pb}$ levels among the different concentrations ranges. In El Sauzal Harbor $(\mathrm{n}=74), \mathrm{Cu}$ 482 was distributed between the $<$ ERL $(29.7 \%)$ and ERL-ERM $(70.3 \%)$ ranges, whereas in Ensenada 483 Harbor $(n=147)$, it occurred between the <ERL (10.4\%), ERL-ERM $(75.3 \%)$ and $>$ ERM $(14.3 \%)$ 
484

485

ranges (Table 7). In El Sauzal, Ni was also distributed between the $<E R L$ and ERL-ERM ranges (17.6 and $82.4 \%$, respectively), whereas in Ensenada it was between the ERL-ERM and >ERM ranges (47.8 and 52.2\%, respectively) (Table 7). Finally, $\mathrm{Pb}$ was distributed only between the first two concentration ranges in both harbors, though the proportion of this metal in the $<E R L$ range was only $14.3 \%$ in Ensenada Harbor, but $98.6 \%$ in El Sauzal Harbor (Table 7). The rest of the metals (Cd and $\mathrm{Zn}$ ) showed similar behaviors in their distribution ranges (Table 7).

\section{Conclusions}

Despite the high total metal concentrations measured in the sediments of Ensenada and El Sauzal harbors, their Al-normalized values generally correspond to what would be expected from their aluminosilicate content. Results from $\mathrm{EF}_{\mathrm{Me}}, \mathrm{PLI}, \mathrm{I}_{\text {geo }}$ and effects range (Figures 7 and 8, and Tables 6 and 7, respectively) clearly demonstrate that the inner parts of both harbors contain higher levels of metals relative to the outer parts (with cores $1 \mathrm{E}$ and $2 \mathrm{~S}$ generally the most enriched), and that Ensenada is the more trace metal-enriched harbor of the two. In terms of particular elements, Cd ranked among the most enriched in both harbors (e.g., Figure 7, Tables 6 and 7); however, $\mathrm{Cu}$ and $\mathrm{Ni}$ in Ensenada and, to a much lesser extent, $\mathrm{Zn}$ in both harbors, are the metals that can potentially cause adverse effects to local living resources. Overall, PLI values for both harbors were reasonable ( $\leq 2.47)$, with an important percentage (79.3$86.1 \%$ ) of the analyzed metals belonging to $I_{\text {geo }}$ classes 0 and 1 (unpolluted to moderatelly polluted). Hence, despite the apparently high total trace element concentrations measured in both Mexican harbors, the levels of most of the metals are not greatly enriched in these sediments and do not represent a threat to the local biota, a consideration that is of the utmost importance when contamination issues are at stake.

\section{Acknowledgments}


511 We thank Rafael Blanco-Betancourt, who collected all cores for this study, and two anonymous

512 reviewers, whose insightful comments greatly improved the content of the manuscript. This

513 research was partially supported by grants from Fondo Sectorial SEMARNAT-CONACYT

514 (SEMARNAT-2002-C01-0016) and Fondo CONACYT-BC (SINVE 001-EC) to M.A. Huerta-Diaz.

515

516

517 References

518

519 Ackermann, F., Bergmann, H., Schleichert, U., 1983. Monitoring of heavy metals in coastal and

520 estuarine sediments - A question of grain size: $<20 \mu \mathrm{m}$ versus $<60 \mu \mathrm{m}$. Environmental

$521 \quad$ Technology Letters, 4, 317-328.

522 Alvarez-Borrego, J., Alvarez-Borrego, S., 1982. Temporal and spatial variability of temperature in 523 two coastal lagoons. CalCOFI Reports, 23, 188-198.

524 Alvarez-Sánchez, L.G., Hernández, R., Durazo, R., 1988. Drift patterns of lagrangian tracers in

525 Todos Santos Bay. Ciencias Marinas, 14, 135-162.

526 Angulo, E., 1996. The Tomlinson Pollution Load Index applied to heavy metal, 'Mussel-Watch'

527 data: a useful index to assess coastal pollution. Science of the Total Environnment, 187, 19-

$528 \quad 56$.

529 Balistrieri, L.S., Murray, J.W., 1986. The surface chemistry of sediments from the Panama Basin:

530 The influence of Mn oxides on metal adsorption. Geochimica et Cosmochimica Acta, 50,

$531 \quad 2235-2243$.

532 Birch, G.F., 2003. A test of normalization methods for marine sediment, including a new post-

533 extraction normalization (PEN) technique. Hydrobiologia, 492, 5-13.

534 Blake, A.C., Chadwick, D.B., Zirino, A., Rivera-Duarte, I., 2004. Spatial and temporal variations

535 in copper speciation in San Diego Bay. Estuaries, 27, 437-447.

536 Carignan, R., Tessier, A., 1988. The co-diagenesis of sulfur and iron in acid lake sediments of

537 southwestern Québec. Geochimica et Cosmochimica Acta, 52, 1179-1188. 
Cauwet G., 1987. Influence of sedimentological features on the distribution of trace metals in marine sediments. Marine Chemistry, 22, 221-234.

Carreón-Martínez, L.B., Huerta-Diaz, M.A., Nava-López, C., Siqueiros-Valencia, A., 2001. Mercury and silver concentrations in sediments from the Port of Ensenada, Baja California, Mexico. Marine Pollution Bulletin, 42, 415-418.

Cauwet, G., 1987. Influence of sedimentological features on the distribution of trace metals in marine sediments. Marine Chemistry, 22, 221-234.

Charlesworth, M., Service, M., 2000. An assessment of metal contamination in northern Irish coastal sediments. Proceedings of the Royal Irish Academy, 100B, 1-12.

City of San Diego, 2005. Annual Receiving Waters Monitoring Report for the Point Loma Ocean

Förstner, U., 1982. Accumulative phases for heavy metals in limnic sediments. Hydrobiologia,

de Groot, A., Zshuppe, K., Salomons, W., 1982. Standardization of methods of analysis for

Coronado-Méndez, C.A., Ramírez-Aguilar, M.A., Czitrom Baus, S., 2003. Actualización de la batimetría del puerto de Ensenada, B.C. México. Cruise PE110502 of May 2002, Technical Report 1-31 A from CICESE, $26 \mathrm{p}$.

heavy metals in sediments. Hydrobiologia, 92, 689-695.

Ergin, M., 1995. Effects of fine grain size on distribution of $\mathrm{Mn}$ in shallow and deep water Black Sea sediments: A comparison between oxic and anoxic depositional environments. GeoMarine Letters, 15, 51-58.

Flores-Vidal X., Ramírez-Aguilar I. and Czitrom-Baus S., 2005. Numerical simulation of the hydrodynamics of a port and effect of a wave-driven seawater pump. Ciencias Marinas, 31,

564 Gibbs, R.J., 1977. Transport phases of transition metals in the Amazon and Yukon rivers.

565 Geological Society of America Bulletin, 88, 661-679. 
566

Goldberg, E.D., Griffin, J.J., Hodge, V., Koide, M., Windom, H., 1979. Pollution history of the Savannah River Estuary. Environmental Science and Technology, 13, 588-594.

Gonzalez-Morales, A.T., Gaxiola Castro, G., 1991. Daily variation of physico-chemical characteristics, biomass, and phytoplankton primary production in an upwelling costal zone of Baja California. Ciencias Marinas, 3, 21-37.

Grant, A., 1990. Multivariate statistical analyses of sediment geochemistry. Marine Pollution Bulletin, 21, 297-299.

Helmke, P.A., Koons, R.D., Schomberg, P.J., Iskandar, I.K., 1977. Determination of trace element contamination of sediments by multielement analysis of clay-size fraction. Environmental Science and Technology, 11, 984-989.

Horowitz, A.J., Elrick, K.A., Hooper, R.P., 1989. The prediction of aquatic sediment-associated trace element concentrations using selected geochemical factors. Hydrological Processes, 3 , 347-364.

Jørgensen, B.B., Boudreau, B.P., 2001. Diagenesis and sediment-water exchange. In: Boudreau, B.P., Jørgensen, B.B. (Eds.). The Benthic Boundary Layer. Oxford University Press, Oxford, 211-244 pp.

Kay, J.T., Conklin, M.H., Fuller, C.C., O'Day, P.A., 2001. Processes of nickel and cobalt uptake by a manganese oxide forming sediment in Pinal Creek, Globe Mining District, Arizona. Environmental Science and Technology, 35, 4719-4725.

Kersten, M., Smedes, F., 2002. Normalization procedures for sediment contaminants in spatial and temporal trend monitoring. Journal of Environmental Monitoring, 4, 109-115.

Li, Y.-H., Schoonmaker, J.E., 2005. Chemical composition and mineralogy of marine sediments. In: Mackenzie, F.T. (Ed.) Sediments, Diagenesis, and Sedimentary Rocks. Vol 7, First Edition: Treatise on Geochemistry, Holland, H.D., Turekian, K.K., Executive Directors, 1-35 pp.

Lin, S., Hsieh, I-J., Huang, K.-M., Wang, C.-H., 2002. Influence of the Yangtze River and grain size on the spatial variations of heavy metals and organic carbon in the East China Sea continental shelf sediments. Chemical Geology, 182, 377-394

page 21 (Huerta-Diaz et al.) 
594 Long, E.R., Macdonald, D.D., Smith, S.L., Calder F.D., 1995. Incidence of adverse biological 595 effects within ranges of chemical concentrations in marine and estuarine sediments. $596 \quad$ Environmental Management, 19, 81-97.

597 Loring, D.H., 1991. Normalization of heavy-metal data from estuarine and coastal sediments.

598 Journal of Marine Science, 48, 101-115.

599 Martin, J.H., Broenkow, W.W., 1975. Cadmium in plankton: Elevated concentrations off Baja 600 California. Science, 190, 884-885.

601 Meador, J.P., Robisch, P.A., Clark, R.C., Jr., Ernest, D.W., 1998. Elements in fish and sediment 602 from the Pacific coast of the United States: Results from the national benthic surveillance 603 project. Marine Pollution Bulletin, 37, 56-66.

604 Müller G., 1979. Schwermetalle in den sedimenten des Rheins - Veranderungen seit. Umschan $605 \quad 79,778-783$.

606 Muñoz-Barbosa, A., Gutiérrez-Galindo, E.A., Segovia-Zavala, J.A., Delgadillo-Hinojosa, F., 607 Sandoval-Salazar, G., 2004. Trace metal enrichment in surficial sediments of the northwest 608 coast of Baja California, Mexico. Marine Pollution Bulletin, 48, 596-603.

609 Murray, J.W., 1975. The interaction of metal ions at the manganese dioxide-solution interface.

610 Geochimica et Cosmochimica Acta, 39, 505-519.

611 Nayar, S., Miller, D.J., Hunt, A., Goh, B.P.L., Chou, L.M., 2007. Environmental effects of 612 dredging on sediment nutrients, carbon and granulometry in a tropical estuary.

613 Environmental Monitoring and Assessment, 127, 1-13.

614 Okbamichael, M., Sañudo-Wilhelmy, S.A., 2004. A new method for the determination of Vitamin $615 \quad B_{12}$ in seawater. Analytica Chimica Acta, 517, 33-38.

616 Osuna-López, J.I., Ortega-Romero, P., Páez-Osuna, F., 1986. Cd, Co, Cr, Cu, Fe, Ni, Pb y Zn

617 en los sedimentos del Puerto y antepuerto de Mazatlán. Ciencias Marinas, 12, 35-45.

618 Pavía, E.G., 2004. La influencia de los ciclones tropicales en la lluvia del noroeste de Baja 619 California y suroeste de California. Geos, 24, 69-72. 
620

621

Peña-Manjarrez, J.L., Helenes, J., Gaxiola-Castro, G., Orellana-Cepeda, E., 2005. Dinoflagellate cysts and bloom events at Todos Santos Bay, Baja California, México, 1999-2000. Continental Shelf Research, 25, 1375-1393.

Pérez -Higuera, I., Chee-Barragán, A., 1984. Sediment transport in Todos Santos Bay. Ciencias Marinas, 10, 31-52.

Salomons, W., Förstner, U., 1984. Metals in the Hydrocycle (pp. 80-81). Berlin: Springer-Verlag.

Santos Bermejo, J.C., Beltrán, R., Gómez Ariza, J.L., 2003. Spatial variations of heavy metals contamination in sediments from Odiel river (Southwest Spain). Environmental International, 29, 69-77.

Santschi, P.H., Nixon, S., Pilson, M., 1984. Accumulation of sediments, trace metals (Pb, Cu) and hydrocarbons in Narragansett Bay, Rhode Island. Estuarine, Coastal and Shelf Science, $19,427-450$.

Schiff, K.C., 2000. Sediment chemistry on the mainland shelf of the Southern California Bight. Marine Pollution Bulletin, 40, 268-276.

Schiff, K., Weisberg, S.B., 1999. Iron as a reference element for determining trace metal enrichment in California coastal shelf sediments. Marine Environmental Research, 48, 161176.

Schropp, S.J., Lewis, F.G., Windom, H.L., Ryan, J.D., Calder, F.D., Burney, L.C., 1990.

Interpretation of metal concentrations in estuarine sediments of Florida using aluminum as a reference element. Estuaries, 22, 227-235.

Sclater, F.R., Boyle, E., Edmond, J.M., 1976. On the marine geochemistry of nickel. Earth and Planetary Science Letters, 31, 119-128.

Segovia-Zavala, J.A., Delgadillo-Hinojosa, F., Alvarez-Borrego, S., 1998. Cadmium in the coastal upwelling area adjacent to the California - Mexico Border. Estuarine, Coastal and Shelf Science, $46,475-481$.

Summers, J.K., Wade, T.L., Engle, V.D., Malaeb, Z.A., 1996. Normalization of metal concentrations in estuarine sediments from the Gulf of Mexico. Estuaries, 19, 581-594. 
647 Tessier, A., Fortin, D., Belzile, N., DeVitre, R.R., Leppard, G.G., 1996. Metal sorption to

648 diagenetic iron and manganese oxyhydroxides and associated organic matter: Narrowing the

649 gap between field and laboratory measurements. Geochimica et Cosmochimica Acta, 60,

$650 \quad 387-404$.

651 Tomlinson, D.L., Wilson, J.G., Harris, C.R., Jeffrey D.W., 1980. Problems in the assessment of 652 heavy-metal levels in estuaries and the formation of a pollution index. Helgoland Marine 653 Research, 33, 566-575.

654 Trivedi, P., Axe, L., 2001. Predicting divalent metal sorption to hydrous Al, Fe, and Mn oxides. 655 Environmental Science and Technology, 35, 1779-1784.

656 Turekian, K.K., Wedepohl, K.H., 1961. Distribution of the elements in some major units of the 657 Earth's crust. Geological Society of America Bulletin, 72, 175-192.

658 Weisberg, S.B., Wilson, H.T., Heimbuch, D.G., Windom, H.L., Summers, J.K., 2004. Comparison 659 of sediment metal:aluminum relationships between the eastern and gulf coasts of the United 660 States. Environmental Monitoring and Assessment, 61, 373-385.

661 Zhang, C., Wang, L., Li, G., Dong, S., Yang, J., Wang, X., 2002. Grain size effect on multi662 element concentrations in sediments from the intertidal flats of Bohai Bay, China. Applied 663 Geochemistry, 17, 59-68.

664 
Figure 1. Location of Ensenada and El Sauzal harbors. The circulation pattern shown in (b) was taken from Peña-Manjarrez et al. (2005).

Figure 2. Profiles of total trace metal concentrations (on a dry weight basis), percentage of grain size $<62.5 \mu \mathrm{m}$ (\%GS) and organic carbon (org-C) for each of the seven cores collected in Ensenada Harbor. Gray symbols represent concentrations below the detection limit.

Figure 3. Profiles of total trace metal concentrations (on a dry weight basis), percentage of grain 676 size $<62.5 \mu \mathrm{m}$ (\%GS) and organic carbon (org-C) for each of the four cores collected in El Sauzal 677 Harbor.

679 Figure 4. Box plots of total trace metal concentrations, organic carbon (org-C) and percentage of 680 grain size $<62.5 \mu \mathrm{m}$ (\%GS) for each one of the sediment cores collected in Ensenada and El 681 Sauzal harbors (open and gray boxes, respectively). Cd concentrations below the detection limit 682 in core $0 \mathrm{E}$ were not considered for the calculation of basic statistics. In this figure, the boundary 683 of the box closest to zero indicates the 25 th percentile, a line within the box marks the median, 684 and the boundary of the box farthest from zero indicates the 75th percentile. Bars above and 685 below the box indicate the 90th and 10th percentiles, respectively.

687 Figure 5. Plots of percentage of grain size $<62.5 \mu \mathrm{m}$ (\%GS) vs. metal concentration and organic 688 carbon (org-C) for sediment cores collected in Ensenada and El Sauzal harbors. Concentrations 689 ( \pm one standard deviation) reported for Point Loma Ocean Outfall (PLOO; City of San Diego, 690 2005), Mazatlan Harbor (MH; Osuna-López et al., 1986), northern Irish coastal sediments (NICS; 691 Charlesworth and Service, 2000), Southern California Bight (SCB), Santa Monica Bay (SMB), 
692

693

694

695

696

697

698

699

700

701

702

703

704

705

706

707

708

709 Figure 8. Pollution load index for each one of the sediment cores (gray bars) and for Ensenada

710 (Ens) and El Sauzal (Sauz) areas (black bars). PLI values of zero, one (dashed line), or larger

711 than one suggest absence of baseline pollutant, presence of them, or progressive deterioration of

712 sediment quality, respectively. 
Figure 1

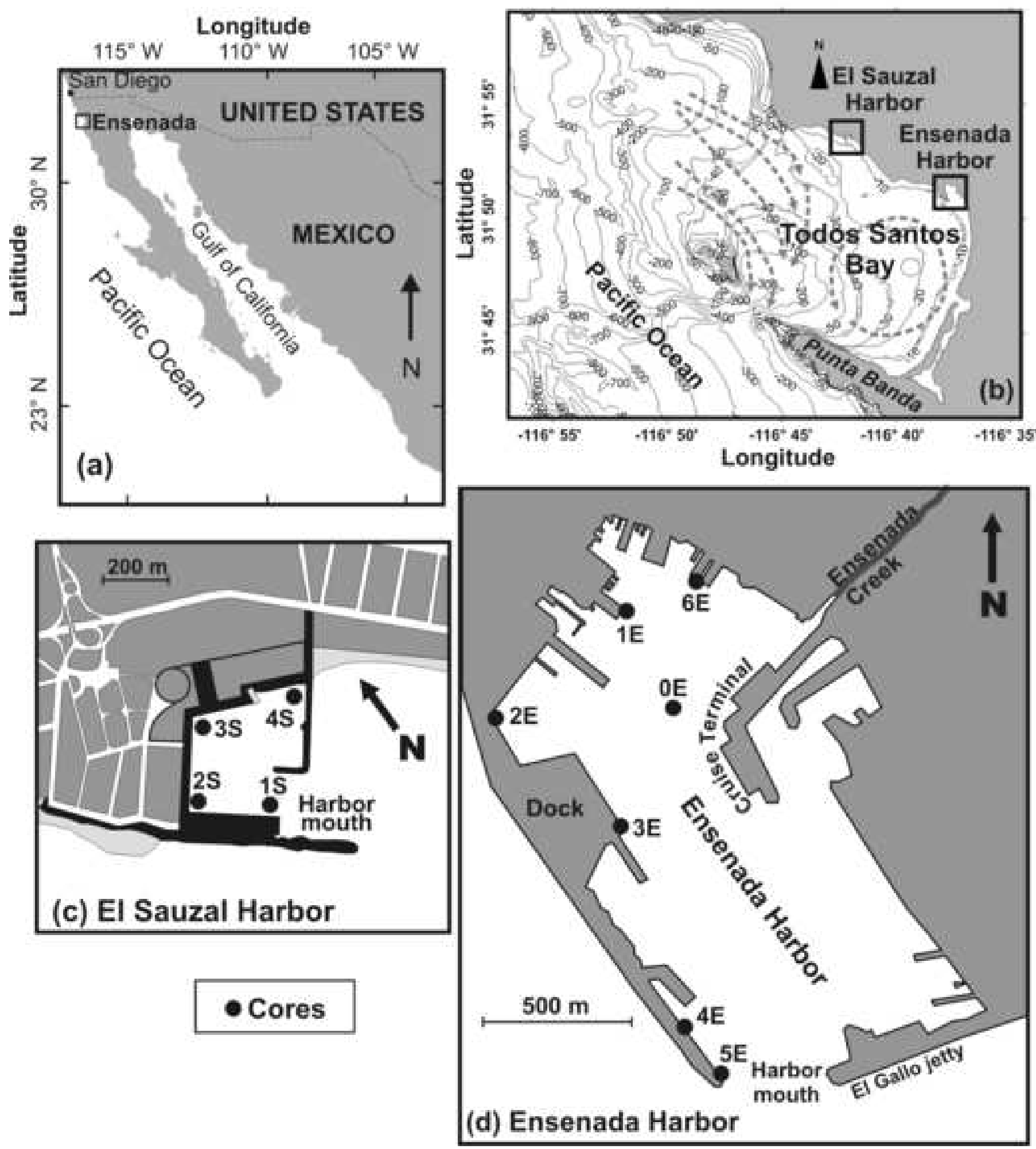


Figure 2a

- $\mathrm{Cu}\left(\mu \mathrm{mol} \mathrm{g}{ }^{-1}\right)$

$0 \quad 50 \quad 100 \quad 150 \quad 200 \quad 250$

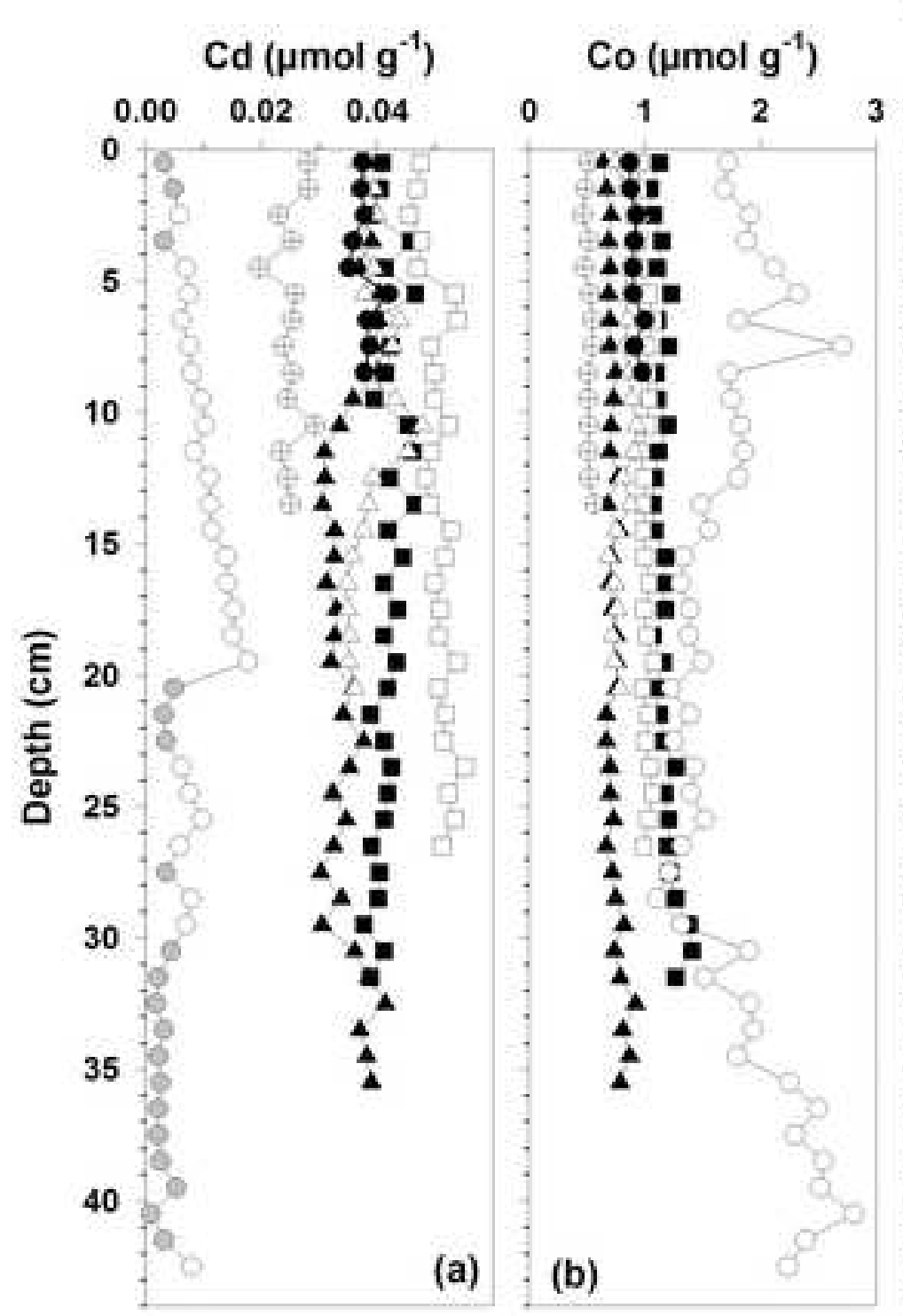

$\mathrm{Cu}\left(\mu \mathrm{mol} \mathrm{g}{ }^{-1}\right)$

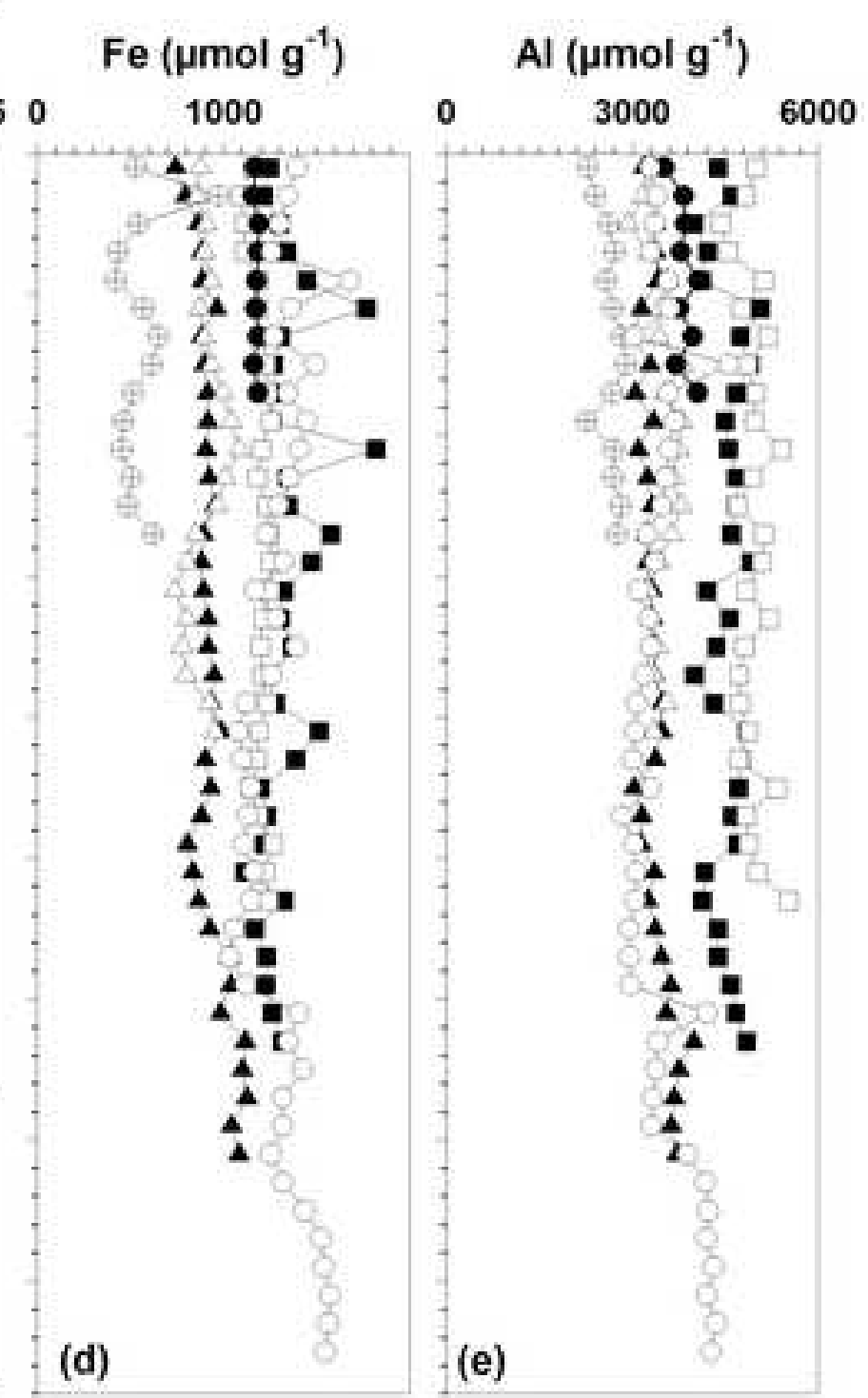


Figure 2b

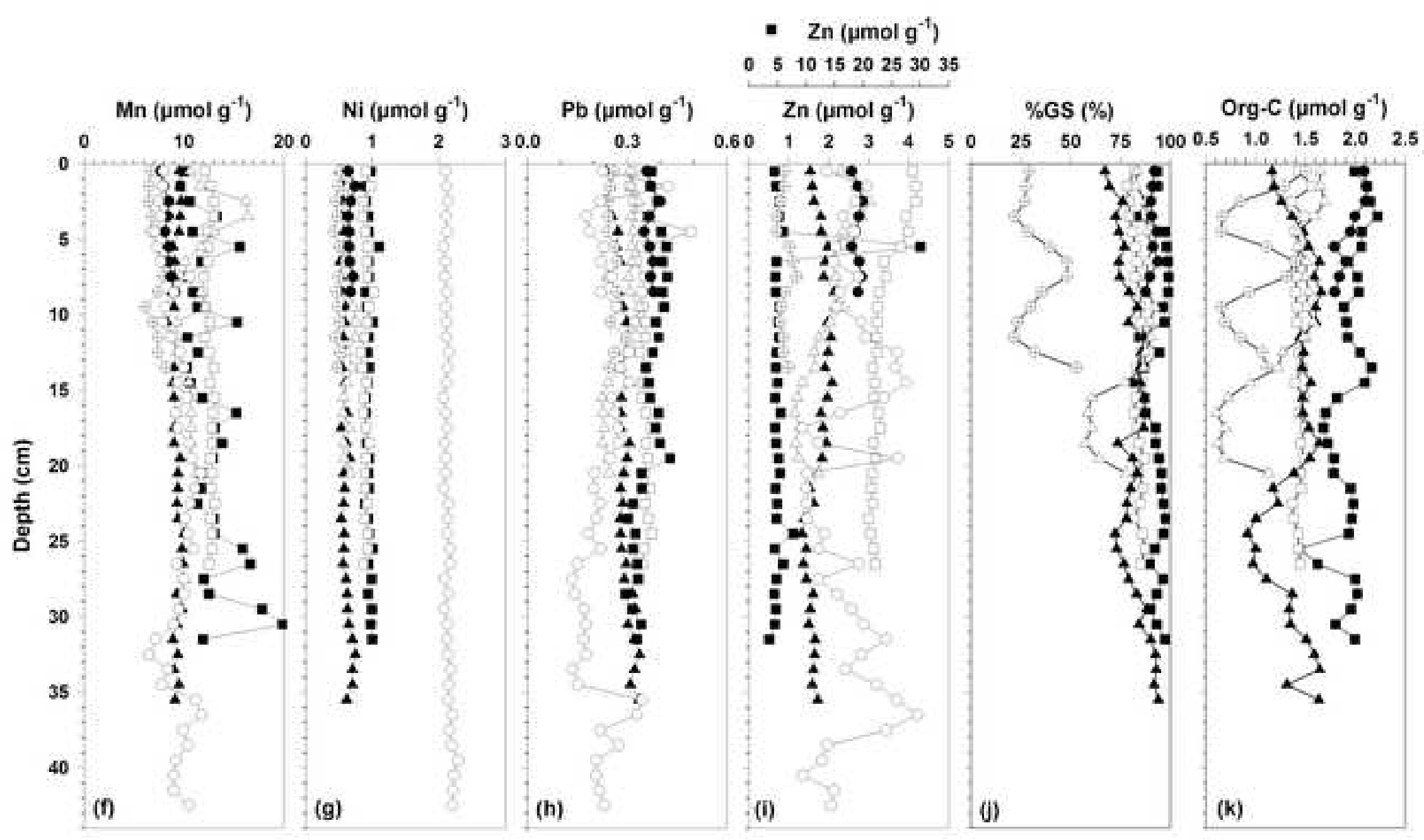


Figure 3a

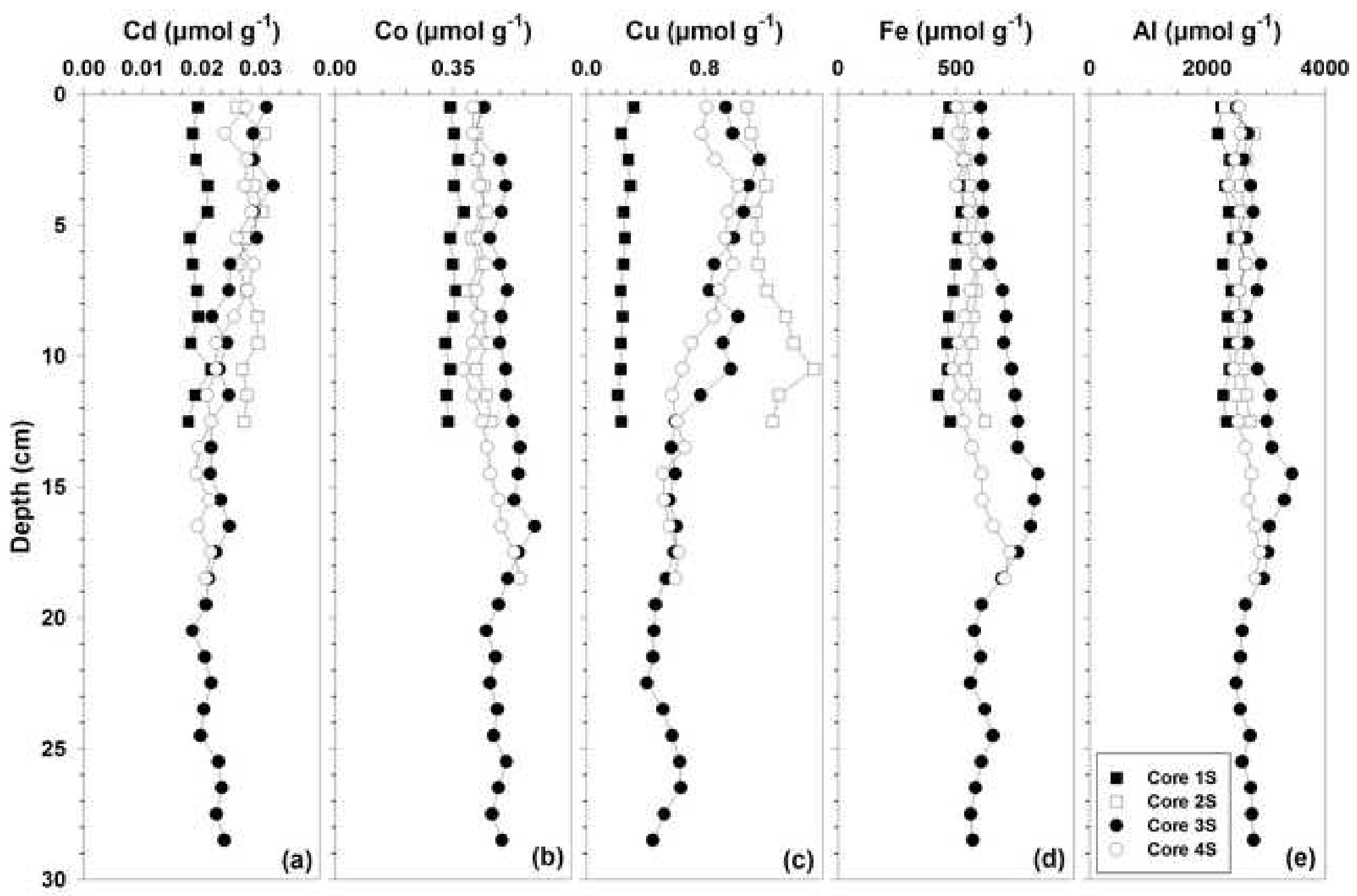


Figure 3b

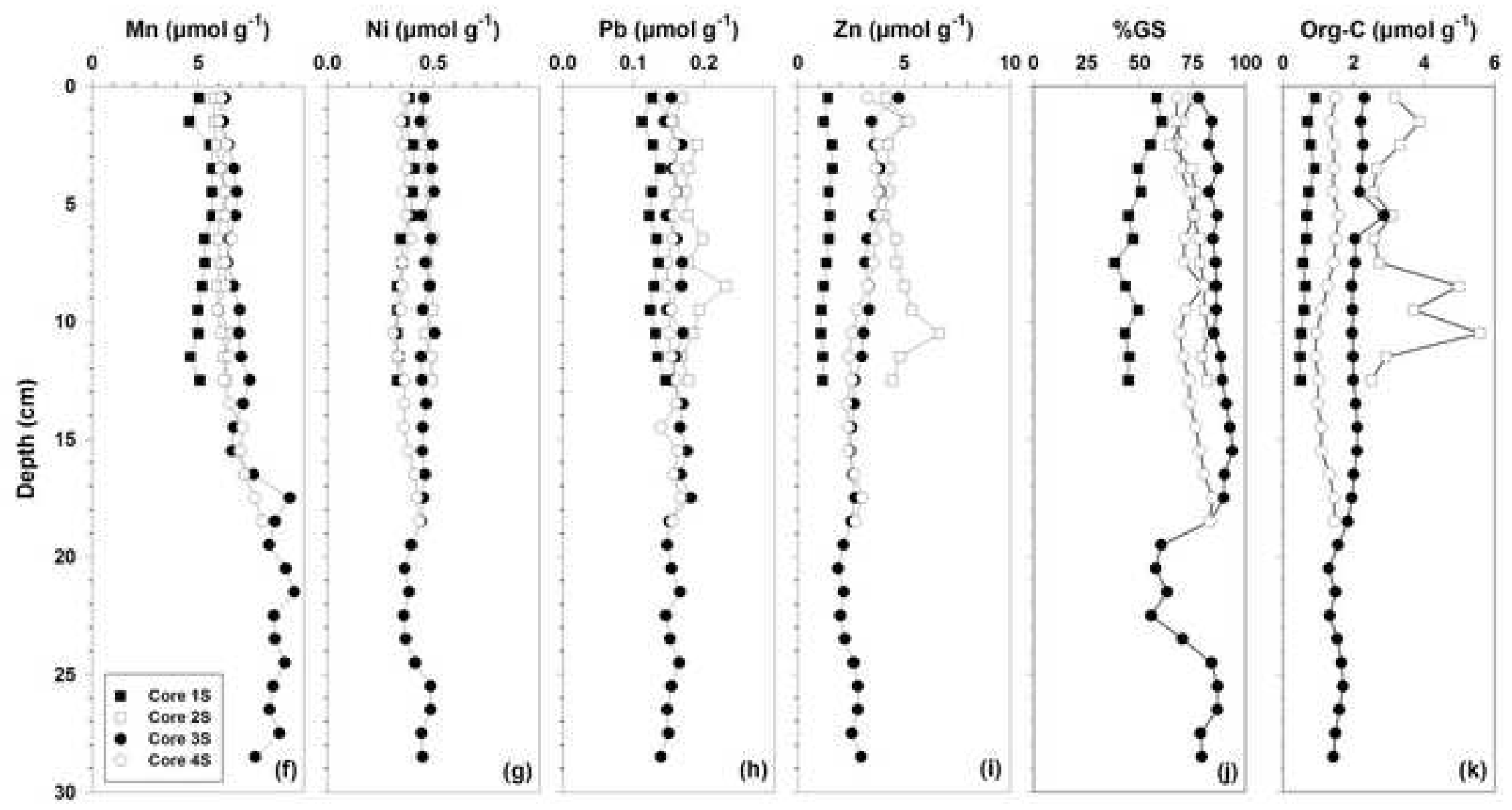


Figure 4
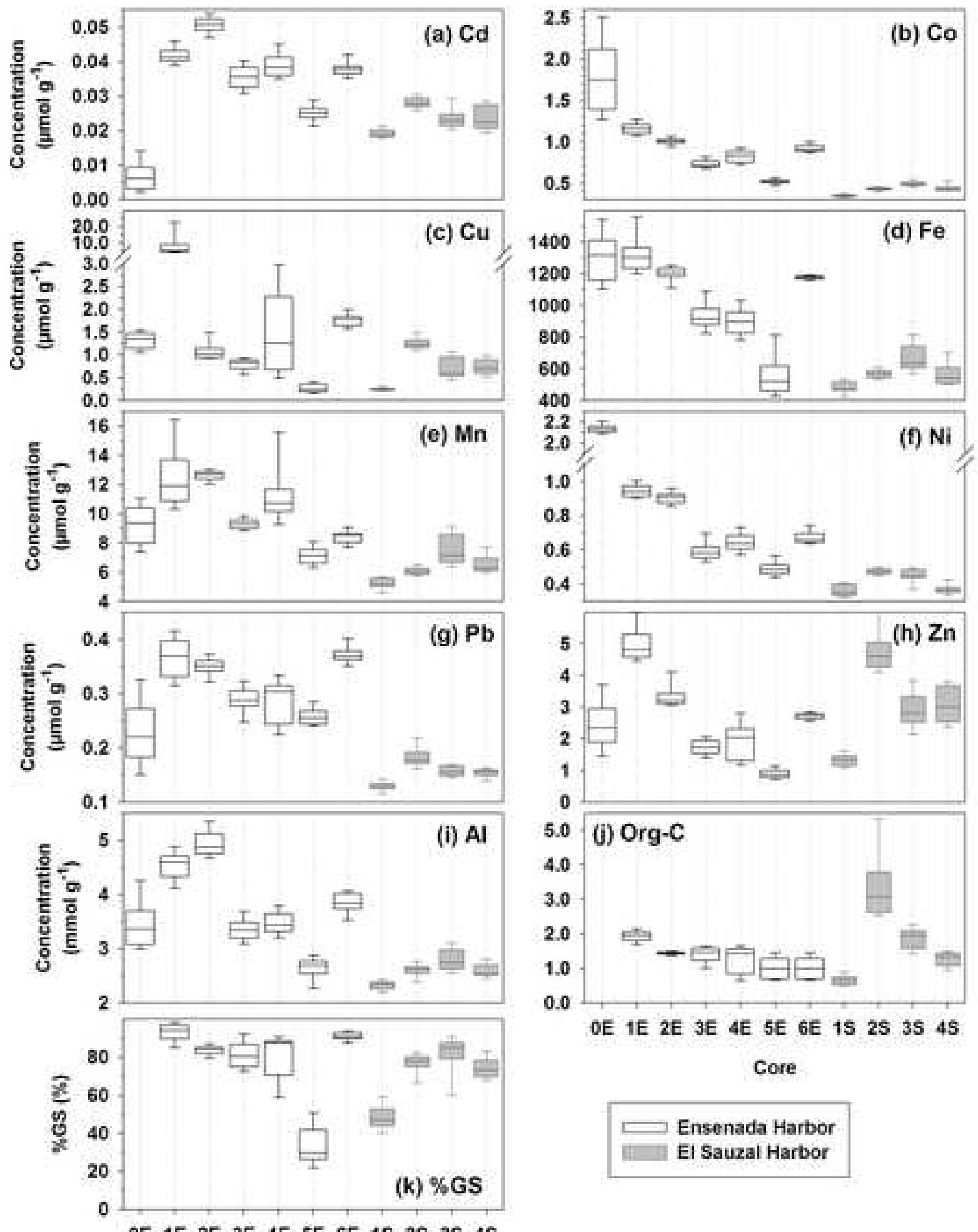

OE TE $2 E$ 3E $4 E$ 5E $6 E$ 1S $2 S$ 3S $4 S$

Core 
Figure 5

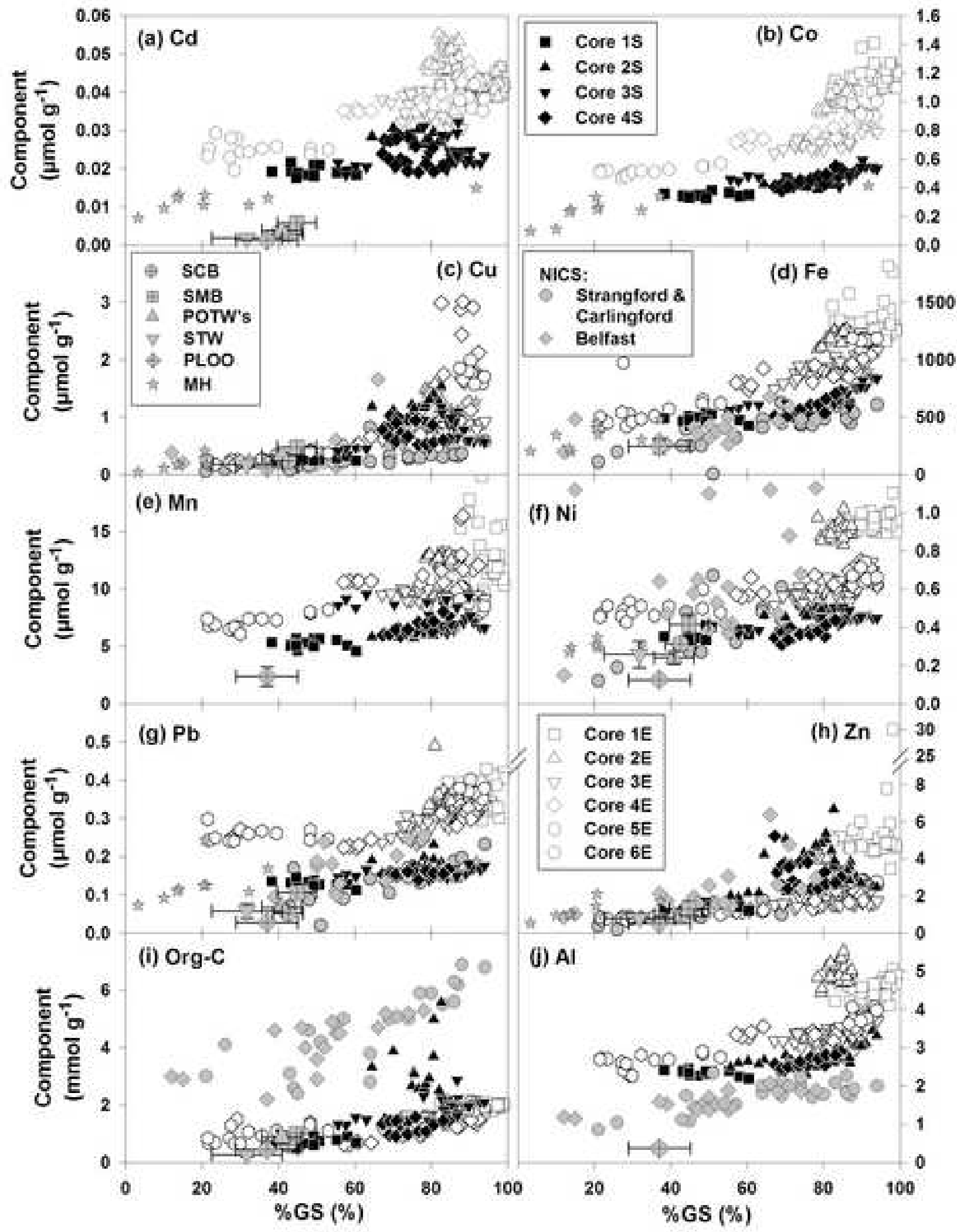


Figure 6

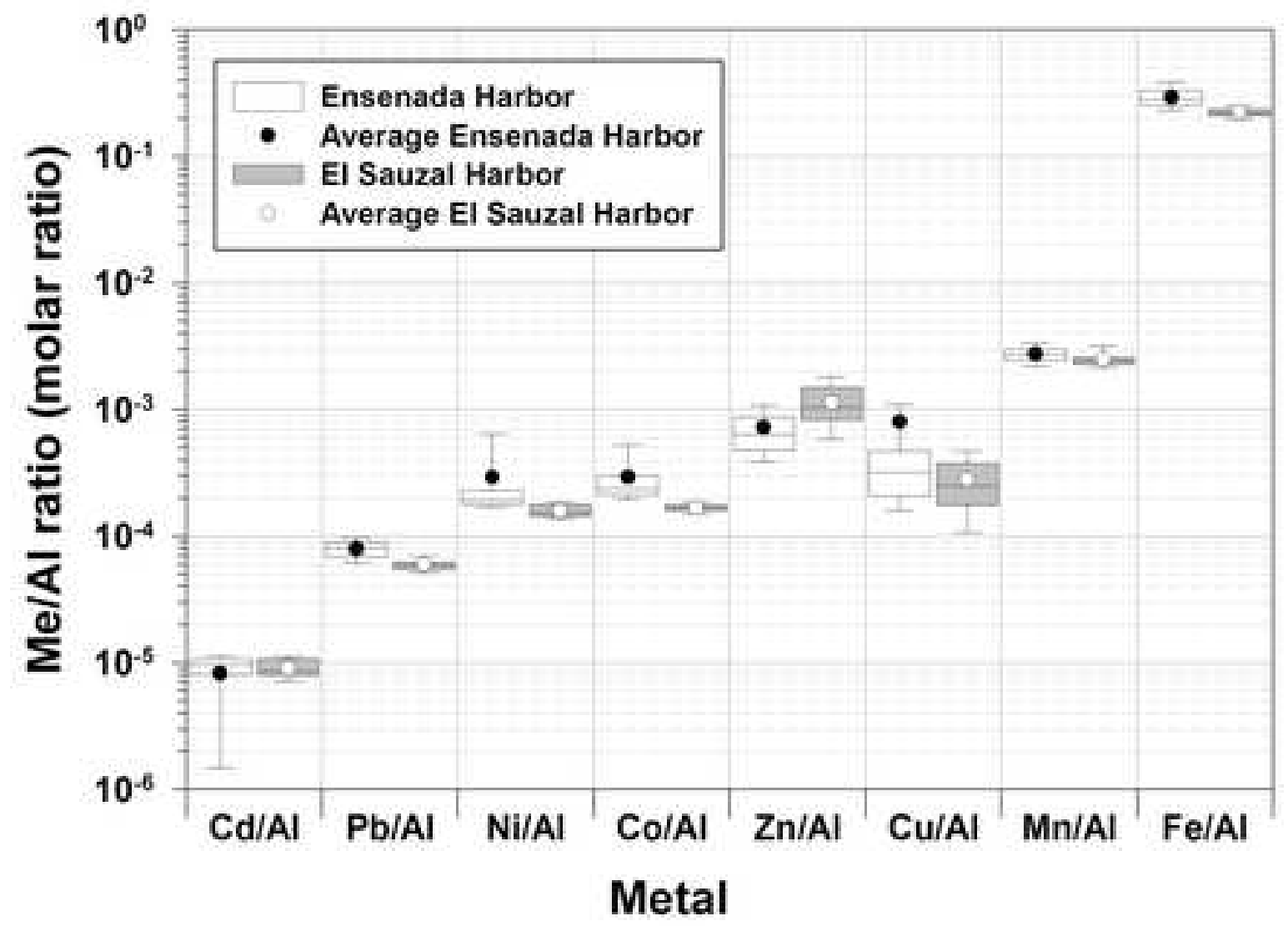


Figure 7
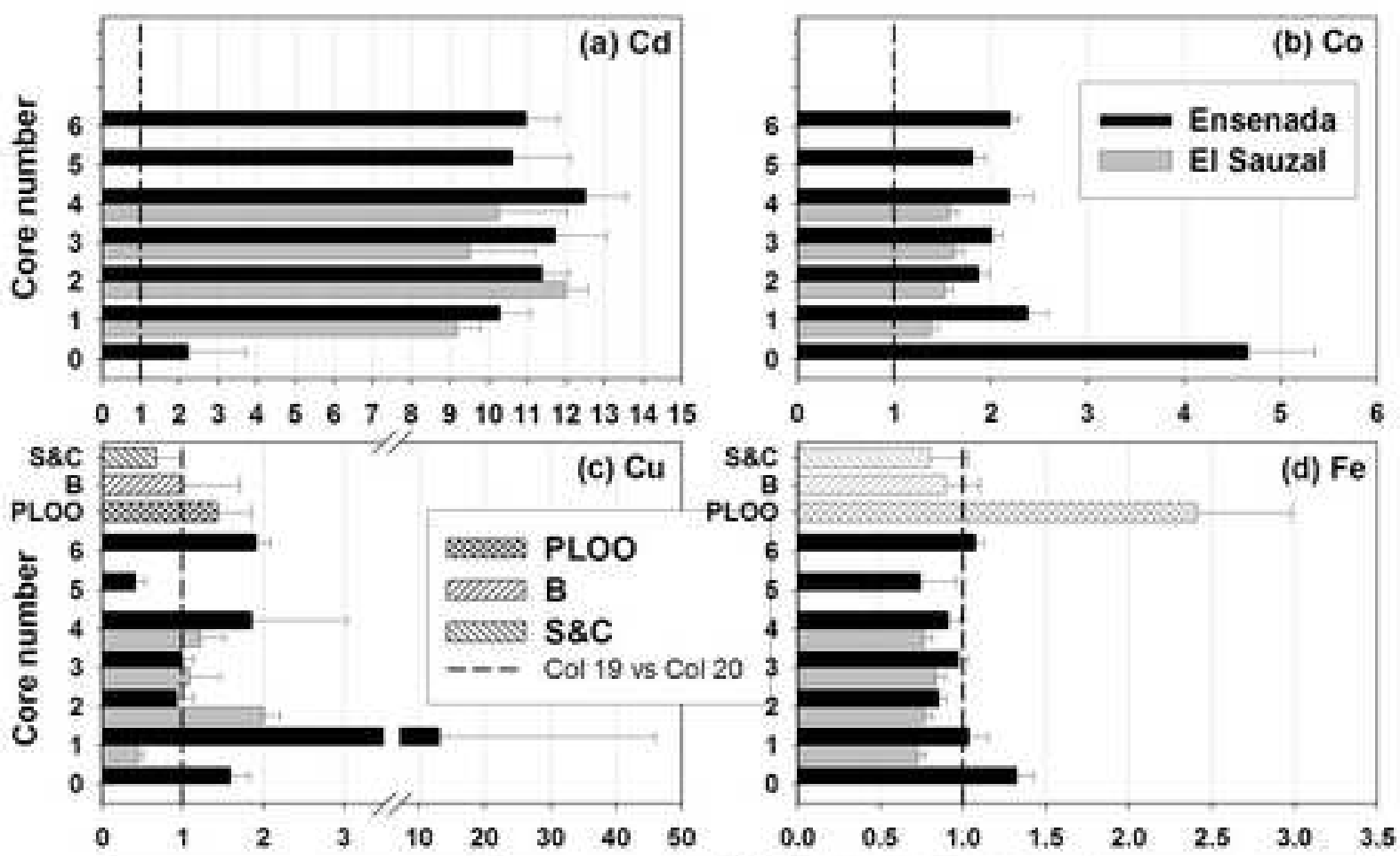

$S \& C$
BLOO
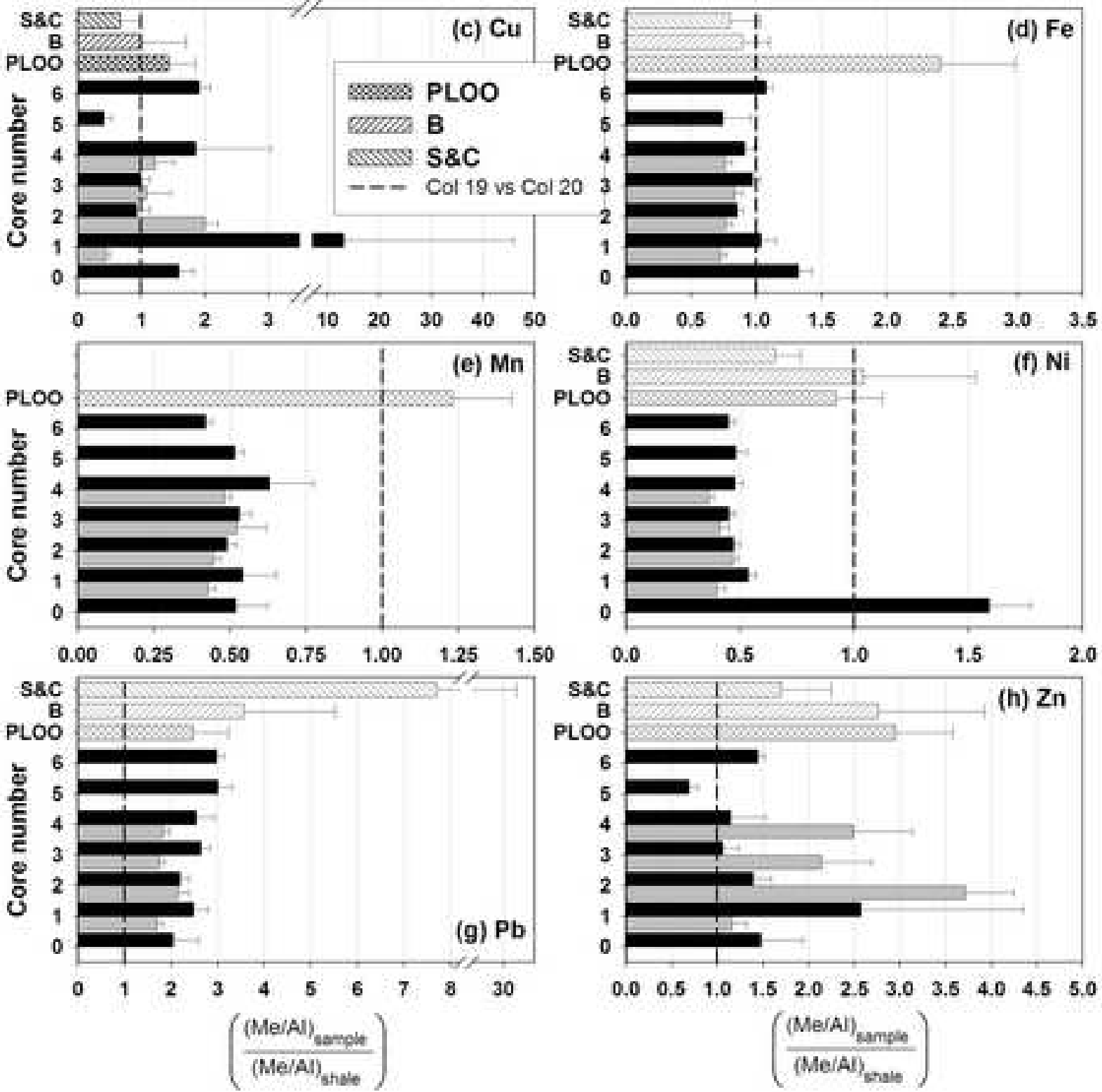
Figure 8

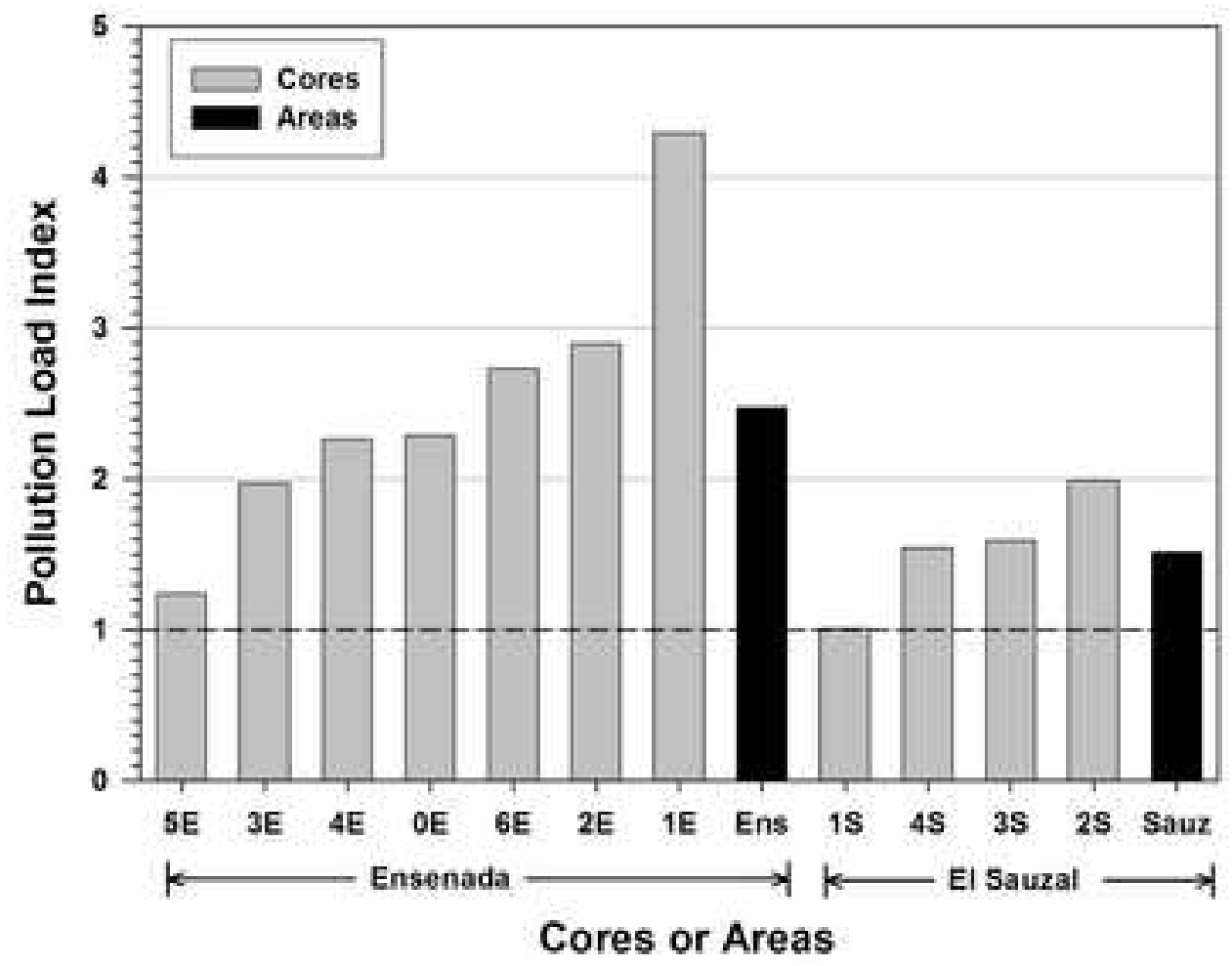


Table 1. Measured $(n=21)$ and certified concentrations ( \pm two standard deviations), and percentages of recovery of Beaufort Chemistry Standard Sediment (BCSS-1; National Research Council of Canada).

\begin{tabular}{cccc} 
Element & $\begin{array}{c}\text { Measured } \\
\text { concentration } \\
\left(\boldsymbol{\mu \mathbf { g ~ g ~ } ^ { - 1 } )}\right.\end{array}$ & $\begin{array}{c}\text { Certified } \\
\text { concentration } \\
\left(\boldsymbol{\mu \mathbf { g ~ g ~ } ^ { - 1 } )}\right.\end{array}$ & $\begin{array}{c}\text { Percentage } \\
\text { of recovery } \\
(\%)\end{array}$ \\
\hline $\mathbf{A l}$ & $(6.5 \pm 1.0) \times 10^{4}$ & $(6.3 \pm 0.2) \times 10^{4}$ & 103 \\
$\mathbf{C d}$ & $0.23 \pm 0.03$ & $0.25 \pm 0.04$ & 90 \\
$\mathbf{C o}$ & $10.8 \pm 0.2$ & $11.4 \pm 2.1$ & 95 \\
$\mathbf{C u}$ & $19.2 \pm 0.7$ & $18.5 \pm 2.7$ & 104 \\
$\mathbf{F e}$ & $(3.23 \pm 0.04) \times 10^{4}$ & $(3.3 \pm 0.1) \times 10^{4}$ & 98 \\
$\mathbf{M n}$ & $220 \pm 10$ & $229 \pm 15$ & 96 \\
$\mathbf{N i}$ & $52.5 \pm 0.3$ & $55.3 \pm 3.6$ & 95 \\
$\mathbf{P b}$ & $22.2 \pm 1.8$ & $22.7 \pm 3.4$ & 98 \\
$\mathbf{Z n}$ & $112 \pm 5$ & $119 \pm 12$ & 94 \\
\hline
\end{tabular}




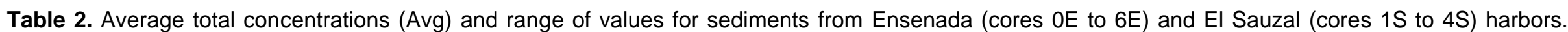

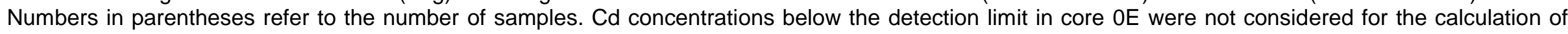
basic statistics.

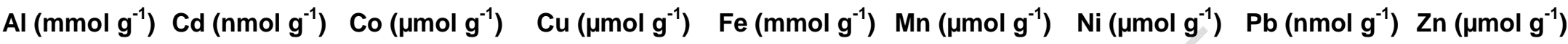

\begin{tabular}{|c|c|c|c|c|c|c|c|c|c|}
\hline $\begin{array}{c}\text { Avg } 0 \mathrm{E}(43) \\
\text { Range } 0 \mathrm{E}\end{array}$ & $\begin{array}{c}3.49 \pm 0.47 \\
2.84-4.56\end{array}$ & $\begin{array}{l}6.8 \pm 4.2 \\
<7.6-18\end{array}$ & $\begin{array}{c}1.79 \pm 0.45 \\
1.11-2.81\end{array}$ & $\begin{array}{c}1.32 \pm 0.19 \\
0.92-1.59\end{array}$ & $\begin{array}{r}1.31 \pm 0.16 \\
1.03-1.68\end{array}$ & $\begin{array}{c}9.3 \pm 1.3 \\
6.5-12\end{array}$ & $\begin{array}{l}2.136 \pm 0.046 \\
2.069-2.293\end{array}$ & $\begin{array}{l}231 \pm 62 \\
135-423\end{array}$ & $\begin{array}{c}2.50 \pm 0.78 \\
1.34-4.22\end{array}$ \\
\hline $\begin{array}{c}\text { Avg 1E (32) } \\
\text { Range 1E }\end{array}$ & $\begin{array}{c}4.53 \pm 0.28 \\
3.99-5.07\end{array}$ & $\begin{array}{l}41.8 \pm 2.4 \\
37.7-46.6\end{array}$ & $\begin{array}{l}1.169 \pm 0.085 \\
1.052-1.411\end{array}$ & $\begin{array}{r}15 \pm 40 \\
4-229\end{array}$ & $\begin{array}{r}1.33 \pm 0.16 \\
1.11-1.82\end{array}$ & $\begin{array}{c}12.7 \pm 2.5 \\
10-20\end{array}$ & $\begin{array}{c}0.948 \pm 0.044 \\
0.892-1.10\end{array}$ & $\begin{array}{l}366 \pm 38 \\
295-429\end{array}$ & $\begin{array}{r}5.8 \pm 4.5 \\
3.5-30\end{array}$ \\
\hline $\begin{array}{l}\text { Avg 2E (27) } \\
\text { Range 2E }\end{array}$ & $\begin{array}{c}4.94 \pm 0.25 \\
4.43-5.52\end{array}$ & $\begin{array}{l}50.6 \pm 2.5 \\
45.5-55.2\end{array}$ & $\begin{array}{l}1.006 \pm 0.043 \\
0.918-1.083\end{array}$ & $\begin{array}{c}1.09 \pm 0.21 \\
0.91-1.58\end{array}$ & $\begin{array}{c}1.200 \pm 0.046 \\
1.09-1.26\end{array}$ & $\begin{array}{l}12.61 \pm 0.35 \\
11.87-13.15\end{array}$ & $\begin{array}{c}0.907 \pm 0.040 \\
0.832-1.02\end{array}$ & $\begin{array}{l}353 \pm 32 \\
307-490\end{array}$ & $\begin{array}{c}3.36 \pm 0.38 \\
2.99-4.18\end{array}$ \\
\hline $\begin{array}{c}\text { Avg 3E (36) } \\
\text { Range 3E }\end{array}$ & $\begin{array}{c}3.36 \pm 0.22 \\
3.00-3.99\end{array}$ & $\begin{array}{l}35.3 \pm 3.4 \\
30.2-41.4\end{array}$ & $\begin{array}{l}0.733 \pm 0.059 \\
0.637-0.919\end{array}$ & $\begin{array}{c}0.79 \pm 0.12 \\
0.53-0.94\end{array}$ & $\begin{array}{l}0.931 \pm 0.089 \\
0.742-0.126\end{array}$ & $\begin{array}{l}9.28 \pm 0.38 \\
8.27-10.0\end{array}$ & $\begin{array}{l}0.593 \pm 0.054 \\
0.518-0.744\end{array}$ & $\begin{array}{l}288 \pm 26 \\
233-337\end{array}$ & $\begin{array}{c}1.73 \pm 0.23 \\
1.33-2.17\end{array}$ \\
\hline $\begin{array}{c}\text { Avg 4E (21) } \\
\text { Range 4E }\end{array}$ & $\begin{array}{c}3.46 \pm 0.23 \\
2.93-3.81\end{array}$ & $\begin{array}{l}38.9 \pm 3.7 \\
34.8-47.8\end{array}$ & $\begin{array}{l}0.823 \pm 0.074 \\
0.695-0.963\end{array}$ & $\begin{array}{c}1.51 \pm 0.90 \\
0.37-3.01\end{array}$ & $\begin{array}{l}0.900 \pm 0.089 \\
0.739-1.084\end{array}$ & $\begin{array}{r}11.2 \pm 1.9 \\
9.2-16.4\end{array}$ & $\begin{array}{l}0.645 \pm 0.055 \\
0.560-0.750\end{array}$ & $\begin{array}{l}285 \pm 40 \\
223-336\end{array}$ & $\begin{array}{c}1.92 \pm 0.58 \\
1.13-3.03\end{array}$ \\
\hline $\begin{array}{c}\text { Avg 5E (14) } \\
\text { Range 5E }\end{array}$ & $\begin{array}{c}2.64 \pm 0.20 \\
2.26-2.90\end{array}$ & $\begin{array}{l}25.0 \pm 2.4 \\
19.6-29.3\end{array}$ & $\begin{array}{l}0.518 \pm 0.028 \\
0.470-0.574\end{array}$ & $\begin{array}{l}0.262 \pm 0.087 \\
0.148-0.418\end{array}$ & $\begin{array}{r}0.56 \pm 0.14 \\
0.42-0.97\end{array}$ & $\begin{array}{l}7.12 \pm 0.62 \\
6.14-8.19\end{array}$ & $\begin{array}{l}0.492 \pm 0.042 \\
0.428-0.600\end{array}$ & $\begin{array}{l}257 \pm 16 \\
241-298\end{array}$ & $\begin{array}{c}0.89 \pm 0.14 \\
0.70-1.2\end{array}$ \\
\hline $\begin{array}{c}\text { Avg 6E (9) } \\
\text { Range 6E }\end{array}$ & $\begin{array}{c}3.84 \pm 0.18 \\
3.52-4.07\end{array}$ & $\begin{array}{l}37.8 \pm 2.0 \\
35.1-42.0\end{array}$ & $\begin{array}{l}0.918 \pm 0.043 \\
0.870-0.999\end{array}$ & $\begin{array}{c}1.76 \pm 0.13 \\
1.57-1.99\end{array}$ & $\begin{array}{c}1.175 \pm 0.011 \\
1.16-1.19\end{array}$ & $\begin{array}{l}8.41 \pm 0.41 \\
7.73-9.07\end{array}$ & $\begin{array}{l}0.671 \pm 0.035 \\
0.637-0.742\end{array}$ & $\begin{array}{l}371 \pm 14 \\
350-400\end{array}$ & $\begin{array}{c}2.72 \pm 0.10 \\
2.57-2.85\end{array}$ \\
\hline $\begin{array}{c}\text { Overall } \\
\text { Avg (182): } \\
\text { Overall } \\
\text { range: }\end{array}$ & $\begin{array}{c}3.81 \pm 0.75 \\
2.26-5.52\end{array}$ & $\begin{array}{l}32 \pm 16 \\
<7.6-55\end{array}$ & $\begin{array}{l}1.10 \pm 0.48 \\
0.470-2.81\end{array}$ & $0.15-229$ & $\begin{array}{l}1.11 \pm 0.26 \\
0.419-1.82\end{array}$ & $\begin{array}{l}10.4 \pm 2.3 \\
6.14-19.9\end{array}$ & $\begin{array}{l}1.07 \pm 0.62 \\
0.428-2.29\end{array}$ & $\begin{array}{l}299 \pm 66 \\
135-490\end{array}$ & $\begin{array}{r}2.9 \pm 2.4 \\
0.70-30\end{array}$ \\
\hline $\begin{array}{c}\text { Avg 1S (13) } \\
\text { Range 1S }\end{array}$ & $\begin{array}{c}2.33 \pm 0.08 \\
2.18-2.44\end{array}$ & $\begin{array}{l}19.2 \pm 1.2 \\
17.7-21.6\end{array}$ & $\begin{array}{l}0.348 \pm 0.015 \\
0.327-0.382\end{array}$ & $\begin{array}{l}0.251 \pm 0.031 \\
0.210-0.320\end{array}$ & $\begin{array}{l}0.483 \pm 0.036 \\
0.423-0.536\end{array}$ & $\begin{array}{l}5.21 \pm 0.37 \\
4.58-5.68\end{array}$ & $\begin{array}{l}0.363 \pm 0.032 \\
0.327-0.411\end{array}$ & $\begin{array}{l}129 \\
112-\end{array}$ & $\begin{array}{c}1.33 \pm 0.19 \\
1.08-1.62\end{array}$ \\
\hline $\begin{array}{c}\text { Avg 2S (13) } \\
\text { Range 2S }\end{array}$ & $\begin{array}{c}2.61 \pm 0.12 \\
2.30-2.81\end{array}$ & $\begin{array}{l}28.2 \pm 1.5 \\
25.9-30.6\end{array}$ & $\begin{array}{l}0.431 \pm 0.020 \\
0.390-0.463\end{array}$ & $\begin{array}{c}1.24 \pm 0.13 \\
1.09-1.54\end{array}$ & $\begin{array}{l}0.570 \pm 0.026 \\
0.527-0.622\end{array}$ & $\begin{array}{l}6.06 \pm 0.24 \\
5.75-6.53\end{array}$ & $\begin{array}{l}0.476 \pm 0.017 \\
0.453-0.504\end{array}$ & $\begin{array}{l}183 \pm 18 \\
156-231\end{array}$ & $\begin{array}{c}4.75 \pm 0.70 \\
4.07-6.66\end{array}$ \\
\hline $\begin{array}{c}\text { Avg 3S (29) } \\
\text { Range 3S }\end{array}$ & $\begin{array}{c}2.81 \pm 0.24 \\
2.49-3.44\end{array}$ & $\begin{array}{l}23.8 \pm 3.5 \\
18.4-32.1\end{array}$ & $\begin{array}{l}0.495 \pm 0.037 \\
0.409-0.592\end{array}$ & $\begin{array}{c}0.72 \pm 0.23 \\
0.41-1.2\end{array}$ & $\begin{array}{l}0.668 \pm 0.085 \\
0.561-0.848\end{array}$ & $\begin{array}{r}7.6 \pm 1.1 \\
6.2-9.6\end{array}$ & $\begin{array}{l}0.448 \pm 0.041 \\
0.361-0.507\end{array}$ & $\begin{array}{l}158 \pm 10 \\
139-181\end{array}$ & $\begin{array}{c}2.92 \pm 0.64 \\
1.90-4.75\end{array}$ \\
\hline $\begin{array}{c}\text { Avg 4S (19) } \\
\text { Range 4S }\end{array}$ & $\begin{array}{c}2.60 \pm 0.14 \\
2.36-2.90\end{array}$ & $\begin{array}{l}23.8 \pm 3.4 \\
19.1-28.8\end{array}$ & $\begin{array}{l}0.444 \pm 0.044 \\
0.380-0.549\end{array}$ & $\begin{array}{c}0.75 \pm 0.17 \\
0.52-1.0\end{array}$ & $\begin{array}{l}0.565 \pm 0.069 \\
0.485-0.729\end{array}$ & $\begin{array}{l}0.59 \\
3.04\end{array}$ & $\begin{array}{l}0.3 \\
0.3\end{array}$ & $\begin{array}{l}154 \\
133\end{array}$ & $\begin{array}{c}3.15 \pm 0.75 \\
2.30-5.23\end{array}$ \\
\hline $\begin{array}{c}\text { Overall } \\
\text { Avg (74): } \\
\text { Overall } \\
\text { range: }\end{array}$ & $\begin{array}{c}2.64 \pm 0.24 \\
2.18-3.44\end{array}$ & $\begin{array}{l}23.8 \pm 3.9 \\
17.7-32.1\end{array}$ & $\begin{array}{l}0.445 \pm 0.062 \\
0.327-0.592\end{array}$ & $\begin{array}{c}0.74 \pm 0.34 \\
0.21-1.5\end{array}$ & $\begin{array}{l}0.592 \pm 0.095 \\
0.423-0.848\end{array}$ & $\begin{array}{c}6.6 \pm 1.2 \\
4.6-9.6\end{array}$ & $\begin{array}{l}0.418 \pm 0.057 \\
0.310-0.507\end{array}$ & $\begin{array}{l}157 \pm 19 \\
112-231\end{array}$ & $\begin{array}{r}3.0 \pm 1.2 \\
1.1-6.7\end{array}$ \\
\hline
\end{tabular}


Table 3. Pearson correlation matrix for the sedimentary geochemical data from Ensenada and EI Sauzal harbors. Core 0E was not included in the analysis because the percentage of grain size $<62.5$ $\mu \mathrm{m}$ (\%GS) and organic carbon (org-C) were not available. Cu and $\mathrm{Zn}$ concentrations at $5.5 \mathrm{~cm}$ depth in core $1 \mathrm{E}$ were also not considered because they represent outliers.

\begin{tabular}{|c|c|c|c|c|c|c|c|c|c|c|}
\hline & Al & Cd & Co & $\mathrm{Cu}$ & $\mathrm{Fe}$ & Mn & $\mathrm{Ni}$ & $\mathbf{P b}$ & $\mathrm{Zn}$ & $\%$ GS \\
\hline & \multicolumn{10}{|c|}{ El Sauzal Harbor $(n=70)$} \\
\hline Cd & 0.14 & & & & & & & & & \\
\hline Co & $0.85^{\star \star *}$ & 0.19 & & & & & & & & \\
\hline $\mathrm{Cu}$ & 0.20 & $0.87^{* * *}$ & 0.26 & & & & & & & \\
\hline $\mathrm{Fe}$ & $0.90^{\star * *}$ & 0.08 & $0.89^{\star \star \star}$ & 0.17 & & & & & & \\
\hline Mn & $0.51^{* * *}$ & -0.10 & $0.72^{\star * *}$ & -0.04 & $0.56^{\star * *}$ & & & & & \\
\hline $\mathrm{Ni}$ & $0.53^{* \star *}$ & $0.53^{* * *}$ & $0.57^{* * *}$ & $0.63^{* * *}$ & $0.57^{\star * \star}$ & 0.24 & & & & \\
\hline $\mathbf{P b}$ & $0.43^{\star \star *}$ & $0.52^{* * *}$ & $0.47^{\star \star \star}$ & $0.74^{* * *}$ & $0.43^{\star * *}$ & 0.21 & $0.61^{* * *}$ & & & \\
\hline $\mathrm{Zn}$ & 0.21 & $0.84^{* * *}$ & 0.25 & $0.94^{* * *}$ & 0.14 & 0.00 & $0.57^{* * *}$ & $0.70^{\star * \star}$ & & \\
\hline$\%$ GS & $0.76^{\star * *}$ & 0.45 & $0.83^{\star \star *}$ & $0.57^{* * *}$ & $0.77^{\star * *}$ & $0.46^{* * *}$ & $0.68^{* * *}$ & $0.59^{\star \star \star}$ & $0.55^{* * *}$ & \\
\hline \multirow[t]{2}{*}{ Org-C } & 0.32 & $0.69^{* \star *}$ & 0.31 & $0.84^{* * *}$ & 0.28 & 0.07 & $0.70^{\star \star \star}$ & $0.77^{\star \star *}$ & $0.84^{* \star \star}$ & $0.54^{* * *}$ \\
\hline & \multicolumn{10}{|c|}{ Ensenada Harbor $(n=120)$} \\
\hline Cd & $0.85^{\star \star *}$ & & & & & & & & & \\
\hline Co & $0.84^{* * *}$ & $0.71^{* * *}$ & & & & & & & & \\
\hline $\mathrm{Cu}$ & $0.31^{\star \star *}$ & 0.16 & $0.56^{\star \star \star}$ & & & & & & & \\
\hline $\mathrm{Fe}$ & $0.84^{* * *}$ & $0.74^{* * *}$ & $0.88^{* * *}$ & $0.46^{* * *}$ & & & & & & \\
\hline Mn & $0.66^{\star \star *}$ & $0.63^{* \star *}$ & $0.77^{\star * *}$ & $0.44^{* * *}$ & $0.60^{\star \star \star}$ & & & & & \\
\hline $\mathrm{Ni}$ & $0.92^{* \star *}$ & $0.77^{* * *}$ & $0.93^{* * *}$ & $0.50^{* * *}$ & $0.86^{\star \star \star}$ & $0.73^{* * *}$ & & & & \\
\hline $\mathrm{Pb}$ & $0.72^{\star \star *}$ & $0.60^{\star \star \star}$ & $0.73^{\star * *}$ & $0.36^{* * *}$ & $0.79^{\star \star \star}$ & $0.43^{\star * *}$ & $0.73^{\star * *}$ & & & \\
\hline Zn & $0.75^{\star * *}$ & $0.57^{* * *}$ & $0.89^{* * *}$ & $0.74^{* * *}$ & $0.82^{\star * *}$ & $0.67^{* * *}$ & $0.87^{* * *}$ & $0.72^{\star * \star}$ & & \\
\hline \%GS & $0.63^{* * *}$ & $0.61^{* * *}$ & $0.75^{\star * *}$ & $0.35^{\star * \star}$ & $0.79^{* \star *}$ & $0.53^{\star \star *}$ & $0.62^{\star * *}$ & $0.63^{\star \star \star}$ & $0.62^{* \star *}$ & \\
\hline Org-C & $0.49^{* * *}$ & $0.37^{* * \star}$ & $0.69^{\star \star \star}$ & $0.50^{* * *}$ & $0.74^{* * *}$ & $0.30^{* * *}$ & $0.58^{\star * *}$ & $0.69^{\star * *}$ & $0.72^{* * *}$ & $0.71^{* * *}$ \\
\hline
\end{tabular}


Table 4. Results of PCA applied to sedimentary geochemical data gathered at Ensenada and EI Sauzal harbors. Core OE was not included in this analysis because the percentage of grain size $<62.5 \mu \mathrm{m}$ (\%GS) and organic carbon (org-C) were not available. $\mathrm{Cu}$ and $\mathrm{Zn}$ concentrations at $5.5 \mathrm{~cm}$ depth in core $1 \mathrm{E}$ were also not considered because they represent outliers.

\begin{tabular}{ccccc}
\hline Harbor & Component & Eigenvalues & $\begin{array}{c}\text { Explained } \\
\text { variance } \\
(\%)\end{array}$ & $\begin{array}{c}\text { Accumulated } \\
\text { Variance (\%) }\end{array}$ \\
\hline Ensenada & 1 & 5.40 & 49.1 & 49.1 \\
Ensenada & 2 & 3.39 & 30.8 & 79.9 \\
El Sauzal & 1 & 4.80 & 43.6 & 43.6 \\
El Sauzal & 2 & 4.16 & 37.8 & 81.4 \\
\hline
\end{tabular}

\begin{tabular}{|c|c|c|c|c|}
\hline \multicolumn{5}{|c|}{ Component loadings } \\
\hline \multirow{2}{*}{$\begin{array}{l}\text { Geochemical } \\
\text { factor }\end{array}$} & \multicolumn{2}{|c|}{ El Sauzal Harbor } & \multicolumn{2}{|c|}{ Ensenada Harbor } \\
\hline & PC1 & $\mathrm{PC2}$ & PC1 & PC2 \\
\hline $\mathrm{Al}$ & 0.17 & 0.90 & 0.92 & 0.25 \\
\hline $\mathrm{Cd}$ & 0.89 & -0.03 & 0.94 & 0.04 \\
\hline Co & 0.20 & 0.95 & 0.77 & 0.58 \\
\hline $\mathrm{Cu}$ & 0.97 & 0.06 & 0.07 & 0.87 \\
\hline $\mathrm{Fe}$ & 0.13 & 0.94 & 0.77 & 0.53 \\
\hline $\mathrm{Mn}$ & -0.11 & 0.76 & 0.71 & 0.28 \\
\hline $\mathrm{Ni}$ & 0.66 & 0.50 & 0.83 & 0.45 \\
\hline $\mathrm{Pb}$ & 0.75 & 0.36 & 0.64 & 0.50 \\
\hline $\mathrm{Zn}$ & 0.95 & 0.05 & 0.58 & 0.75 \\
\hline$\% G S$ & 0.52 & 0.76 & 0.63 & 0.48 \\
\hline Org-C & 0.89 & 0.18 & 0.35 & 0.78 \\
\hline
\end{tabular}


Table 5. Average ratios of Ensenada $(n=182)$ to El Sauzal $(n=74)$ enrichment factors $\left(E F_{\mathrm{Me}(E n s e n a d a)} / \mathrm{EF}_{\mathrm{Me}(\mathrm{El}}\right.$ sauzal) $)$ for the different elements analyzed. The associated errors were calculated by error propagation analysis. For the special case of $\mathrm{Cd}, \mathrm{Ni}$ and $\mathrm{Cu}$, results are presented with and without some of the cores that showed anomalously elevated $\mathrm{EF}_{\mathrm{Me}}$ values.

\begin{tabular}{lcc} 
Element & $\begin{array}{c}\mathrm{EF}_{\text {Me(Ensenada) }} / \mathrm{EF}_{\text {Me(El Sauzal) }} \\
\text { (molar ratio) }\end{array}$ & $\begin{array}{c}\text { Propagated } \\
\text { error }\end{array}$ \\
\hline $\mathrm{Zn}$ & 0.63 & 0.48 \\
$\mathrm{Cd}$ & 0.91 & 0.43 \\
$\mathrm{Cd}$ (without core 0E) & 1.1 & 0.2 \\
$\mathrm{Mn}$ & 1.1 & 0.3 \\
$\mathrm{Fe}$ & 1.3 & 0.3 \\
$\mathrm{~Pb}$ & 1.3 & 0.3 \\
$\mathrm{Co}$ & 1.7 & 0.8 \\
$\mathrm{Ni}$ & 1.8 & 1.2 \\
$\mathrm{Ni}$ (without core 0E) & 1.2 & 0.2 \\
$\mathrm{Cu}$ & 2.9 & 12.4 \\
$\mathrm{Cu}$ (without core 1E) & 1.1 & 0.8 \\
\hline
\end{tabular}


Table 6. Metals distributed according to their geoaccumulation index $\left(\mathrm{I}_{\text {geo }}\right)$. The $\mathrm{I}_{\text {geo }}$ classes (in parentheses) consist of 7 grades of pollution intensity (Santos Bermejo et al., 2003): $0=$ unpolluted, $1=$ unpolluted to moderately polluted, $2=$ moderately polluted, $3=$ moderately to strongly polluted, $4=$ strongly polluted, $5=$ strongly to very strongly polluted, and $6=$ very strongly polluted.

\begin{tabular}{|c|c|c|c|c|c|c|c|}
\hline \multirow{2}{*}{ Core } & \multicolumn{7}{|c|}{$I_{\text {geo }}\left(I_{\text {geo }}\right.$ class) } \\
\hline & $<0(0)$ & $0-1(1)$ & $1-2(2)$ & $2-3(3)$ & $3-4(4)$ & $4-5(5)$ & $>5(6)$ \\
\hline $\mathrm{OE}$ & $\mathrm{Al}, \mathrm{Mn}$ & $\mathrm{Fe}, \mathrm{Zn}, \mathrm{Cu}, \mathrm{Ni}, \mathrm{Cd}, \mathrm{Pb}$ & Co & ---- & ---- & . & ---- \\
\hline $1 \mathrm{E}$ & $\mathrm{Mn}, \mathrm{Ni}$ & $\mathrm{Al}, \mathrm{Fe}$ & $\mathrm{Co}, \mathrm{Pb}, \mathrm{Zn}$ & $\mathrm{Cu}$ & $\mathrm{Cd}$ & - & ---- \\
\hline $2 E$ & $\mathrm{Mn}, \mathrm{Ni}, \mathrm{Fe}$ & $\mathrm{Cu}, \mathrm{Al}, \mathrm{Zn}$ & $\mathrm{Co}, \mathrm{Pb}$ & --- & $\mathrm{Cd}$ & ---- & ----- \\
\hline $3 E$ & $\mathrm{Ni}, \mathrm{Mn}, \mathrm{Cu}, \mathrm{Fe}, \mathrm{Al}, \mathrm{Zn}$ & $\mathrm{Co}, \mathrm{Pb}$ & ---- & ----- & $\mathrm{Cd}$ & ----- & ----- \\
\hline $4 \mathrm{E}$ & $\mathrm{Ni}, \mathrm{Mn}, \mathrm{Fe}, \mathrm{Al}, \mathrm{Zn}$ & $\mathrm{Cu}, \mathrm{Co}, \mathrm{Pb}$ & ----- & ---- & $\mathrm{Cd}$ & ---- & ----- \\
\hline $5 \mathrm{E}$ & $\mathrm{Cu}, \mathrm{Ni}, \mathrm{Mn}, \mathrm{Zn}, \mathrm{Fe}, \mathrm{Al}$ & $\mathrm{Co}, \mathrm{Pb}$ & ---- & $\mathrm{Cd}$ & ---- & ----- & ----- \\
\hline $6 \mathrm{E}$ & $\mathrm{Mn}, \mathrm{Ni}, \mathrm{Cu}, \mathrm{Fe}, \mathrm{Zn}, \mathrm{Al}$ & $\mathrm{Co}, \mathrm{Pb}$ & ----- & $\mathrm{Cd}$ & ---- & ----- & ----- \\
\hline $\mathrm{CP}^{*}$ & $47.6[30]$ & $31.7[20]$ & $9.5[6]$ & $4.8[3]$ & $6.3[4]$ & 0 & 0 \\
\hline $1 S$ & $\mathrm{Ni}, \mathrm{Mn}, \mathrm{Cu}, \mathrm{Fe}, \mathrm{Al}, \mathrm{Zn}, \mathrm{Co}, \mathrm{Pb}$ & ---- & & $\mathrm{Cd}$ & ---- & ---- & ---- \\
\hline $2 S$ & $\mathrm{Mn}, \mathrm{Ni}, \mathrm{Fe}, \mathrm{Al}, \mathrm{Co}$ & $\mathrm{Cu}, \mathrm{Pb}$ & $\mathrm{Zn}$ & $\mathrm{Cd}$ & ---- & ---- & ---- \\
\hline $3 S$ & $\mathrm{Ni}, \mathrm{Mn}, \mathrm{Fe}, \mathrm{Al}, \mathrm{Cu}$ & $\mathrm{Co}, \mathrm{Pb}, \mathrm{Zn}$ & $-\cdots$ & $\mathrm{Cd}$ & ---- & ----- & ----- \\
\hline $4 S$ & $\mathrm{Ni}, \mathrm{Mn}, \mathrm{Fe}, \mathrm{Al}, \mathrm{Cu}, \mathrm{Co}$ & $\mathrm{Pb}, \mathrm{Zn}$ & & $\mathrm{Cd}$ & ----- & ----- & ----- \\
\hline $\mathrm{CP}^{*}$ & $66.7[24]$ & $19.4[7]$ & $2.8[1]$ & $11.1[4]$ & 0 & 0 & 0 \\
\hline$O P^{\star \star}$ & $54.5[54]$ & $27.3[27]$ & $7.1[7]$ & $7.1[7]$ & $4.0[4]$ & 0 & 0 \\
\hline
\end{tabular}


Table 7. Effects range-low (ERL) and range-median (ERM) guideline values for trace metals (on a dry weight basis) and percent incidence of sediment concentration values in concentration ranges defined by the two guideline values.

\begin{tabular}{|c|c|c|c|c|c|c|}
\hline \multirow{2}{*}{ Harbor } & \multirow{2}{*}{ Element } & $\begin{array}{c}\mathrm{ERL} \\
(\mu \mathrm{mol} / \mathrm{g})\end{array}$ & $\begin{array}{c}\mathrm{ERM} \\
(\mu \mathrm{mol} / \mathrm{g})\end{array}$ & \multicolumn{3}{|c|}{$\begin{array}{l}\text { Percent (ratios) incidence for each } \\
\text { concentration range }{ }^{b}\end{array}$} \\
\hline & & \multicolumn{2}{|c|}{ Guidelines $^{a}$} & $<$ ERL & ERL-ERM & $>$ ERM \\
\hline Ensenada & $\mathrm{Cd}$ & 0.011 & 0.085 & $19.2(35 / 182)$ & $80.8(147 / 182)$ & $0.0(0 / 182)$ \\
\hline El Sauzal & $\mathrm{Cd}$ & 0.011 & 0.085 & $0.0(0 / 74)$ & $100(74 / 74)$ & $0.0(0 / 74)$ \\
\hline Ensenada & $\mathrm{Cu}$ & 0.54 & 4.25 & $10.4(19 / 182)$ & $75.3(137 / 182)$ & $14.3(26 / 182)$ \\
\hline El Sauzal & $\mathrm{Cu}$ & 0.54 & 4.25 & $29.7(22 / 74)$ & $70.3(52 / 74)$ & $0.0(0 / 74)$ \\
\hline Ensenada & $\mathrm{Ni}$ & 0.225 & 1.05 & $0.0(0 / 182)$ & $47.8(87 / 182)$ & $52.2(95 / 182)$ \\
\hline El Sauzal & $\mathrm{Ni}$ & 0.225 & 1.05 & $17.6(13 / 74)$ & $82.4(61 / 74)$ & $0.0(0 / 74)$ \\
\hline Ensenada & $\mathrm{Pb}$ & 0.356 & 0.879 & $14.3(26 / 182)$ & $85.7(156 / 182)$ & $0.0(0 / 182)$ \\
\hline El Sauzal & $\mathrm{Pb}$ & 0.356 & 0.879 & $98.6(73 / 74)$ & $1.4(1 / 74)$ & $0.0(0 / 74)$ \\
\hline Ensenada & $\mathrm{Zn}$ & 2.29 & 6.27 & $47.3(86 / 182)$ & $51.6(94 / 182)$ & $1.1(2 / 182)$ \\
\hline El Sauzal & $\mathrm{Zn}$ & 2.29 & 6.27 & $24.3(18 / 74)$ & $74.3(55 / 74)$ & $1.4(1 / 74)$ \\
\hline
\end{tabular}

a Taken from Long et al. (1995); ${ }^{b}$ Percentage and number of data entries within each concentration range divided by the total number of entries for all ranges. 